Portland State University

PDXScholar

$11-6-2012$

\title{
Temporal and Crustal Effects on Differentiation of Tholeiite to Calcalkaline and Ferro-trachytic Suites, High Lava Plains, Oregon, USA
}

Martin J. Streck

Portland State University, streckm@pdx.edu

Anita L. Grunder

Oregon State University

Follow this and additional works at: https://pdxscholar.library.pdx.edu/geology_fac

Part of the Geology Commons

Let us know how access to this document benefits you.

\section{Citation Details}

Streck, M. J., and A. L. Grunder (2012), Temporal and crustal effects on differentiation of tholeiite to calcalkaline and ferrotrachytic suites, High Lava Plains, Oregon, USA, Geochemistry, Geophysics, Geosystems, 13, Q0AN02.

This Article is brought to you for free and open access. It has been accepted for inclusion in Geology Faculty Publications and Presentations by an authorized administrator of PDXScholar. Please contact us if we can make this document more accessible: pdxscholar@pdx.edu. 


\title{
Temporal and crustal effects on differentiation of tholeiite to calcalkaline and ferro-trachytic suites, High Lava Plains, Oregon, USA
}

\author{
Martin J. Streck \\ Department of Geology, Portland State University, Portland, Oregon 97207-0751, USA \\ (streckm@pdx.edu)
}

\author{
Anita L. Grunder \\ Department of Geosciences, Oregon State University, Corvallis, Oregon 97331, USA
}

[1] Strongly bimodal, basalt-rhyolite volcanism of the High Lava Plains Province of Oregon followed the Middle Miocene flood basalts of the Pacific Northwest and extends to recent time. During the 8 m.y. of volcanism recorded in the central High Lava Plains, in western Harney Basin, three distinct mafic magmatic trends originate from primitive high-alumina olivine tholeiites (HAOT); they are tholeiitic, calcalkaline and ferro-trachytic. Tholeiitic basalts occur throughout the history and their compositions are derived by crystal fractionation while traversing the crust and mixing with evolved mafic magmas. Scavenging of apatite from crustal rocks and minor contamination with felsic melts accounts for $\mathrm{P}$, incompatible element enrichments and increasing tilts of incompatible element patterns with differentiation. The calcalkaline mafic suite occurs in temporal association with abundant silicic volcanism and is the only suite with $\mathrm{Fe}$ decreasing with $\mathrm{Mg}$. Calcalkaline compositions are derived from evolved tholeiitic basalt by crystal fractionation coupled with assimilation of felsic crust or crustal melts. The ferro-trachytic suite occurs mainly late, is highly enriched in incompatible element with patterns parallel to tholeiites from which it is derived by protracted fractionation and recharge. The three suites primarily reflect changes in magma flux and crustal interactions in time. High magma flux promotes crustal melting and contamination of tholeiite to make the calcalkaline suite. On the other hand, ferrotrachytic magmas erupted mainly late in the sequence, during magmatic waning and after significant basaltification of the crust.

Components: 15,400 words, 12 figures, 1 table.

Keywords: HAOT; basalt differentiation; calcalkaline trend; high lava plains; phosphorous enrichment; trachyandesite.

Index Terms: 1033 Geochemistry: Intra-plate processes (3615, 8415); 1037 Geochemistry: Magma genesis and partial melting (3619); 1065 Geochemistry: Major and trace element geochemistry.

Received 14 May 2012; Revised 18 September 2012; Accepted 24 September 2012; Published 6 November 2012.

Streck, M. J., and A. L. Grunder (2012), Temporal and crustal effects on differentiation of tholeiite to calcalkaline and ferrotrachytic suites, High Lava Plains, Oregon, USA, Geochem. Geophys. Geosyst., 13, Q0AN02, doi:10.1029/2012GC004237.

Theme: Genesis of Continental Intraplate Magmatism - the Example From the Pacific Northwest, USA 


\section{Introduction}

[2] The High Lava Plains of Oregon together with the Columbia, Snake River, and Owyhee volcanic plateaus, distinguish the Pacific Northwest as one of the great intracontinental Cenozoic volcanic provinces of the world. The volcanic suite of the High Lava Plains ranges from about $12 \mathrm{Ma}$ to Recent and is strongly bimodal. Basaltic rocks are separated by a sparsely populated gap of about 15 weight $\% \mathrm{SiO}_{2}$ from rhyolites that are mainly high-silica varieties (74 to 78 weight percent $\mathrm{SiO}_{2}$ ) [Streck and Grunder, 2008; Ford, 2011]. Most of the basalts of the High Lava Plains suite are strongly oceanic in character; they are low-K olivine tholeiites to tholeiites with high $\mathrm{Al}_{2} \mathrm{O}_{3}$ and $\mathrm{MgO}$ and have low incompatible trace element concentrations akin to mid-ocean ridge basalts. These are the regionally distinctive highalumina olivine tholeiites (HAOT) [Hart et al., 1984; Hart, 1985; Draper, 1991] that have been used as bellwether for the behavior of the underlying mantle in space and time. Carlson [1984] and Carlson and Hart [1987] make the case that the lithospheric mantle beneath the Oregon Plateau, which includes the Owyhee Plateau and High Lava Plains and the adjacent northwest Basin and Range, was swept away and replaced by depleted asthenospheric mantle. The broad decline in radiogenic mantle signatures in Miocene to Recent basalts from the Snake River Plain westward across the Oregon Plateau has been interpreted as declining westward contribution of lithospheric mantle or Yellowstone Plume mantle, or both [Leeman, 1982; Carlson and Hart, 1987; Camp and Ross, 2004; Graham et al., 2009].

[3] The regionally dominant tholeiites are accompanied by subordinate calcalkaline and ferrobasaltic to trachybasaltic suites of mafic volcanic rocks. We here focus on the western Harney Basin, in the central High Lava Plains, where basaltic volcanic rocks of these three types crop out: tholeiitic, calcalkaline and ferro-trachytic. We consider the mantle and crustal processes that gave rise to the compositional diversity among the broadly basaltic rocks and the implications of temporal variations in liquid lines of descent on modification of the crust through persistent basaltic magmatism.

\section{Volcanic Rocks of the Western Harney Basin}

[4] The western Harney Basin lies in the middle of the High Lava Plains, a northwest trending volcanic plateau about $\sim 300 \mathrm{~km}$ long and $70 \mathrm{~km}$ wide, which lies at the northwest margin of the Basin and Range Province in southeast Oregon. We have selected the western Harney Basin for study because of the wide compositional range among basaltic to intermediate volcanic rocks that span from $\sim 8$ to $2 \mathrm{Ma}$ and because numerous vents could be sampled (Figure 1). The mafic to intermediate rocks occur most commonly as lava flows a few to $10 \mathrm{~m}$ thick or as tephra near scoria- and spatter-cone vent complexes. Basaltic units in the western Harney Basin are oldest on the south and north margins of the High Lava Plains and younger units are concentrated in the middle. Mafic to intermediate compositions also occur as sparse quenched inclusions in silicic lavas and tuffs or as pumices in tuffs. The western Harney Basin also has abundant silicic volcanic rocks, ranging from 8.3 to $6.4 \mathrm{Ma}$, in keeping with the westward younging sweep of rhyolite volcanism in the High Lava Plains and adjacent northwest Basin and Range [MacLeod et al., 1976; Jordan et al., 2004; Ford, 2011]. Iron Mountain, a rhyolite dome complex with an age of $2.9 \mathrm{Ma}$ (Figure 1), is the only center too young to be consistent with the westward sweep. The most prominent regional stratigraphic marker is the 7.1Ma Rattlesnake Tuff, with its inferred source in the western Harney Basin (Figure 1) [Streck and Grunder, 1995].

[5] The composite stratigraphic sequence of the western Harney Basin includes lava flows and vents of HAOT spanning from 8.2 to $\sim 1 \mathrm{Ma}$ (Figure 2). These are punctuated by two ignimbrites, the Rattlesnake Tuff and the tuff of Buckaroo Lake (6.8 Ma) as well as rhyolite domes ranging from 7.7 to $5.7 \mathrm{Ma}$. Two other regionally distributed ash flow tuffs, the 9.7 Ma Devine Canyon Tuff and the 8.4 Ma Prater Creek Tuff [Walker, 1979; Jordan et al., 2004] were likely deposited throughout the Harney Basin but have not been found in exposures in the area of this study. Calcalkaline basaltic andesites to andesites occur in the middle of the section, ranging in age from at least 7.7 to $6.7 \mathrm{Ma}$, but in one case yielded a $2.2 \mathrm{Ma}$ age. Ferrobasaltic to trachybasaltic andesite units are stratigraphically high, 5.4 Ma and younger, but 7.1 Ma mafic magmas that are recorded by rare basaltic andesitic inclusions in the Rattlesnake Tuff are also assigned to this suite [Streck and Grunder, 1999].

[6] In more detail and in chronostratigraphic order, the suite of samples considered here includes 8.2-Ma inflated HAOT pahoehoe flows with ropy surfaces exposed under the Rattlesnake Tuff in the northern part of the Abert Rim fault scarp (Figure 1), on the 


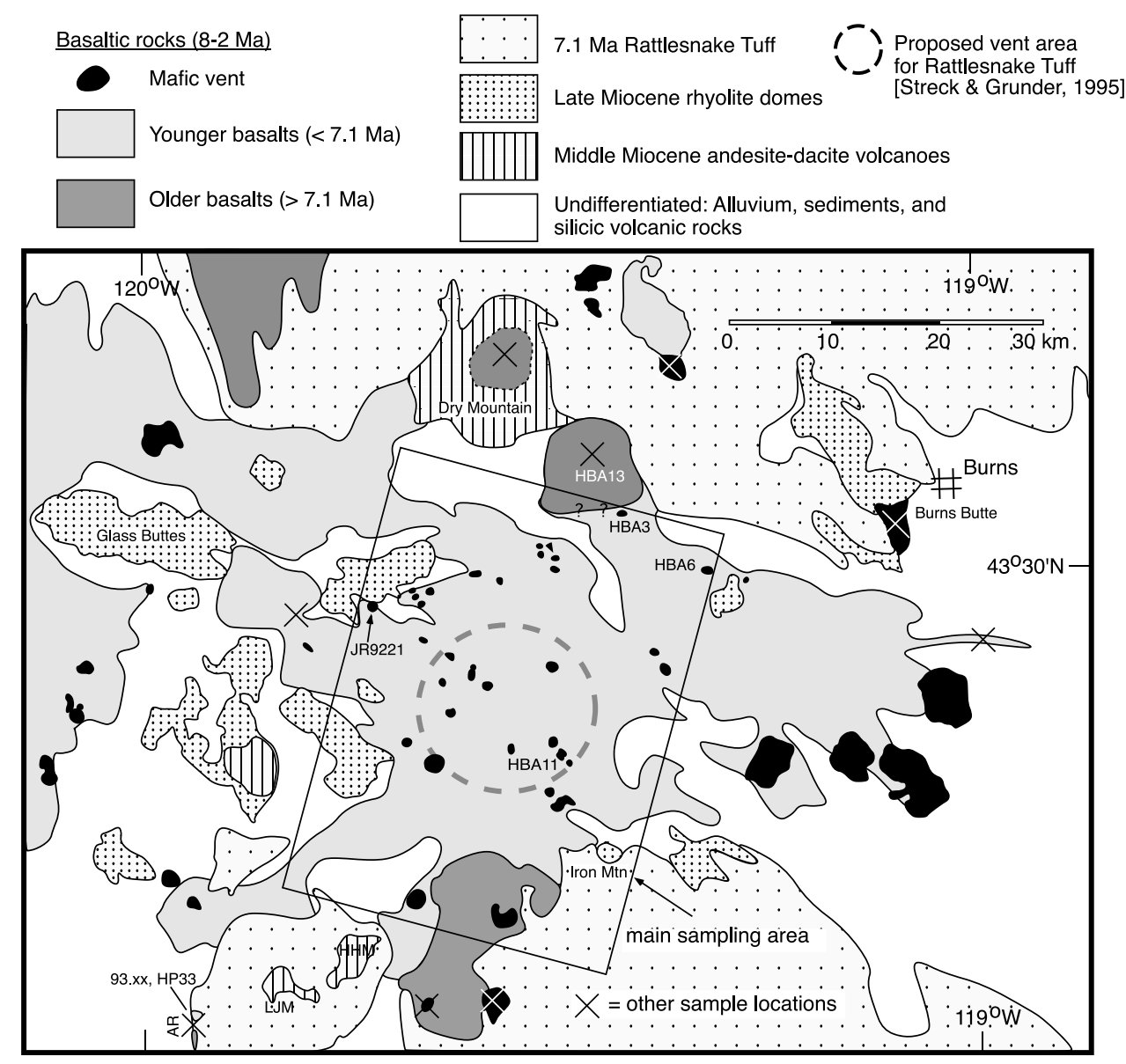

Figure 1. Simplified geologic map of the central High Lava Plains, Oregon (modified from Greene et al. [1972] and Walker et al. [1967]). Rectangle delineates main sampling area of Harney Basin mafic rocks. "Basaltic rocks" includes true basalt to andesite. Locations for some samples of Table 1 are shown. LJM: Little Juniper Mountain, HHM: Horsehead Mountain, AR: Abert Rim, see text.

south side of the High Lava Plains. On the north side of the High Lava Plains, on Dry Mountain, HAOT lava has an age of $7.9 \mathrm{Ma}$ [Iademarco, 2009]. Andesite flows associated with 7.7-Ma rhyolite of Burns Butte are presumed to have an age close to the rhyolite and are only a little older than nearby sections of 7.5-7.6 Ma lavas, on the northern side of the High Lava Plains (in contrast to the age assignment of younger than Rattlesnake Tuff by Greene et al. [1972] - their unit Tobg). The broad shield of Wilson Butte and other nearby mafic vents in the central plain produced 7.5-m.y. old HAOT. These pre-Rattlesnake Tuff mafic flows are part of a pulse of $\sim 8-7.5-\mathrm{Ma}$ basaltic volcanism that occurred throughout the High Lava Plains [Jordan et al., 2004].

[7] Although more than 99\% rhyolitic, the Rattlesnake Tuff has both dacite pumice and sparse HAOT and Fe-rich basaltic andesitic inclusions. Several sills of HAOT invaded the thick rheomorphic section of the Rattlesnake Tuff exposed in
Abert Rim, and are slightly folded and so essentially of the same age as the tuff. One younger HAOT in a nearby location is sandwiched between $7.1 \mathrm{Ma}$ Rattlesnake Tuff and the $6.85 \mathrm{Ma}$ Tuff of Buckaroo Lake. Four mafic vent complexes have erupted magmas that are either Fe-tholeiites or trachyandesites (Figure 1). They crop out around the area inferred to be the source of the Rattlesnake Tuff. Two vents have been dated at 5.4 (HBA3) and 2.4 Ma (JR-92-21) (Table 1) [Jordan et al., 2004]. The latter is Paiute Butte (formerly Squaw Butte), a prominent peak of trachyandesite crisscrossed by dikes. Based on stratigraphic and outcrop relationships, the other two vent complexes are also younger than the Rattlesnake Tuff and probably fall within the same age range. A large field of inflated HAOT basalts with prominent diktytaxitic texture includes the inverted topography of Wright's point [Niem, 1974] and has ages of 2.2-2.5 Ma. A basalt field was identified as Quaternary west 


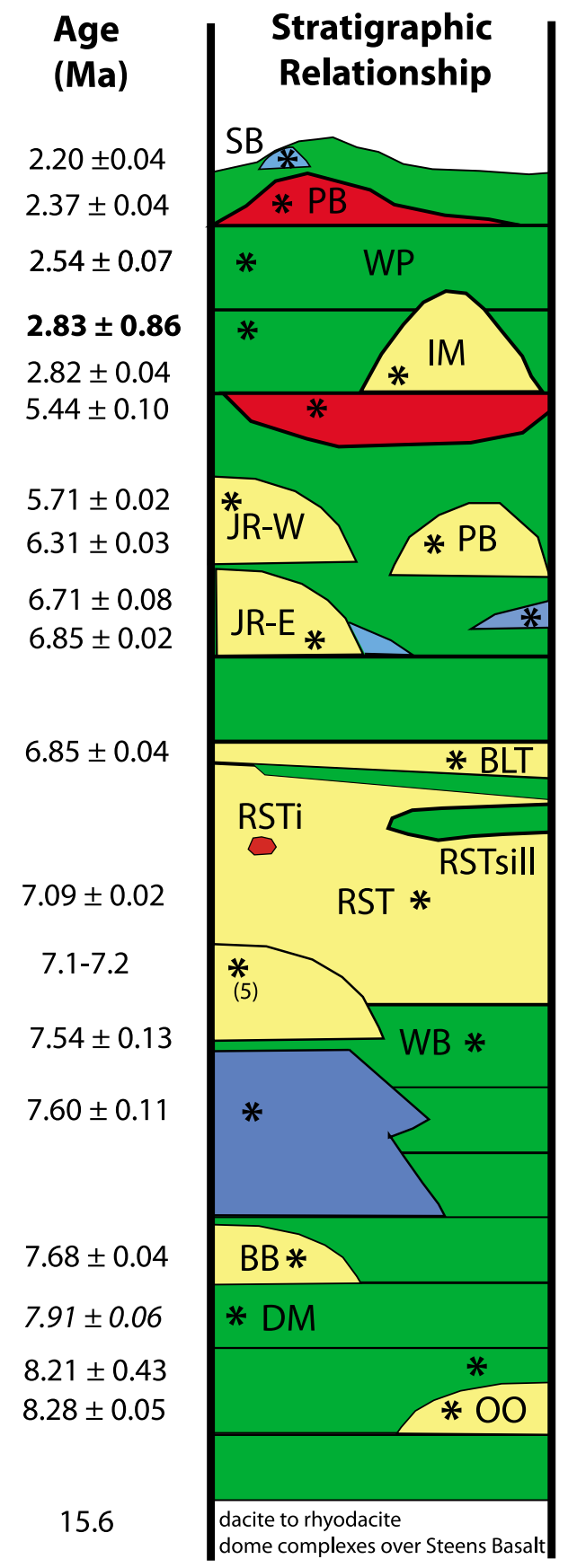

\section{Geographic Name \\ Mafic Sample No.}

Shields Butte

Paiute Butte

Wrights Point

Iron Mountain

Juniper Ridge, West
Palomino Butte

Juniper Ridge, East

$\begin{array}{ll}\text { Palomino Butte } & \text { HBA1, 4, 14, 16 } \\ \text { Juniper Ridge, East } & \text { 209an }\end{array}$

HBA2, 12a, 17

Tuff of Buckaroo Lake

93.1

93.5, 93.2

Rattlesnake Tuff

RST avg inclusion

(5) Horse Mtn, Ram's Butte

Egli Ridge, Sheep Mtn,

Wagontire, Mtn

Wilson Butte

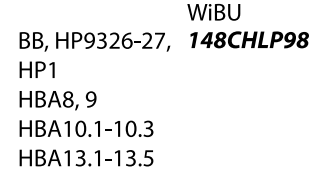

Burns Butte

Dry Mountain

DMT0601

HP-33

Double O Rhyolite

DO basalt

Horsehead Mtn and

Little Juniper Mtn

Figure 2. Schematic stratigraphic section for the volcanic rocks of the High Lava Plains in the western Harney Basin. The section is approximately $500 \mathrm{~m}$ thick and thins to the north and south [Trench et al., 2012]. Except for ignimbrites, the stratigraphic units are made of several lavas. Units shown on the left of the column are exposed in the northern part, and those on the right are exposed in the southern part of the map area. Sample numbers correspond to Table 1. * indicates units with dates, mafic samples with ages indicated in bold sample numbers. Ages are from Jordan et al. [2004] with 1 sigma errors, except: Dry Mountain, which is from Iademarco [2009]; sample 209an from Streck [1994]; and 138CHLP98 (age in bold) presented here (auxiliary material). Color is distinguishing between highalumina olivine basalts (HAOT) in green, calcalkaline lavas in blue, ferro-trachytic lavas in red, and all rhyolitic lava flows and tuffs in yellow. 
of Juniper Ridge on the Burns 1:250,000 geologic map [Greene et al., 1972] but yields an age of $2.83 \pm 0.86 \mathrm{Ma}$ (Table S1 in the auxiliary material) making it comparable in age to the field that includes Wrights Point. ${ }^{1}$

[8] Under the High Lava Plains section lie Miocene rhyodacite dome complexes expressed as paleotopographic highs at Horsehead and Little Juniper Mountain (Figure 1). Farther south along Abert Rim, HAOT lava flows and Rattlesnake Tuff overlie Steens Basalt, which in turn overlies Early Miocene and Oligocene intermediate composition volcanic rocks [Scarberry et al., 2010]. To the north, the High Lava Plains section laps onto other late to mid Miocene tuffs and lava flows, Oligocene volcanic rocks of the John Day Formation, or onto accreted terranes of the Blue Mountains region.

\section{Methods}

[9] Major and trace element results for this study are reported in Table 1, which includes select analyses previously published [cf. Streck and Grunder, 1999, 2008]. Major elements and a suite of trace elements were analyzed by X-ray fluorescence (XRF) at the Washington State University (WSU) GeoAnalytical Laboratory based on the methods of Johnson et al. [1999]. Inductively coupled plasma-mass spectrometry (ICP-MS) was used for a fuller suite of elements on some samples, also at the Geoanalytical Laboratory at WSU following the methods of Knaack et al. [1994]. INAA samples were activated in a 1 MW TRIGA reactor and analyzed at the Radiation Center, Oregon State University details on methods and uncertainties can be found in Streck and Grunder [1997]. New ICP-MS analyses were performed on select samples that were previously analyzed by INAA and XRF to test to what extent low incompatible trace element concentrations by the former two methods are reliable. Overall, older data are in close agreement with ICP-MS data with some exceptions (Table S2 and Figure S1). Older Th data at low concentration need to be taken with caution, although overall trends on normalized incompatible ratio diagrams are not much affected. $\mathrm{Nb}$ concentrations of older analytical runs appear to be slightly too high. Consequently, true mantle normalized pattern should give a positive slope between $\mathrm{Nb}$ and $\mathrm{Ta}$ rather a negative slope (cf. Table S2 and Figures S1, 5, and 6).

\footnotetext{
${ }^{1}$ Auxiliary materials are available in the HTML. doi:10.1029/ $2012 \mathrm{GC} 004237$.
}

[10] Ages are all from data and compilation of Jordan et al. [2004] except for andesite sample 209an taken from Streck [1994] and Dry Mountain basalt [Iademarco, 2009]. One new age is reported (Table S1) which was analyzed by ${ }^{40} \mathrm{Ar}-{ }^{39} \mathrm{Ar}$ methods spelled out in Jordan et al. [2004].

\section{Results}

[11] We subdivide the entire basaltic to intermediate suite of the western Harney Basin into three sub-suites based on major element composition (Figure 2); these are: 1) high-alumina olivine tholeiites (HAOT's), 2) calcalkaline basalt to andesite, and 3) ferrobasalt to trachyandesite, which we dub the ferro-trachytic suite. We further divide the HAOT suite into "older" and "younger" relative to the age of the 7.1 Ma Rattlesnake Tuff. Calcalkaline lavas have ages close to, but mainly older than the tuff (Table 1 and references therein). All lavas belonging to the ferrobasalt-trachyandesite suite are younger than Rattlesnake Tuff or have the same age, as in the case of the Fe-rich basaltic andesitic inclusions of the Rattlesnake Tuff.

[12] The HAOT suite is the most magnesian and has the lowest incompatible trace element concentrations. The evolved end of the HAOT suite coincides with a pronounced bifurcation to the calcalkaline and ferrotrachytic suites. For example, trends of declining $\mathrm{MgO}$ and increasing $\mathrm{FeO}$ or $\mathrm{La} / \mathrm{Yb}$ (Figures $3 \mathrm{a}$ and 4) among HAOT lead to diverging trends, where the calcalkaline suite has decreasing $\mathrm{FeO}$ with increasing $\mathrm{La}$ and $\mathrm{La} / \mathrm{Yb}$ (Figures $4 \mathrm{c}$ and $4 \mathrm{e}$ ). In contrast, the ferro-trachytic suite has increasing $\mathrm{FeO}$ at strongly increasing $\mathrm{La}$ and constant $\mathrm{La} / \mathrm{Yb}$. The bifurcating trends suggest that the evolved HAOT is parental to both the calcalkaline and ferro-trachytic suites. The lack of other types of primitive magmas is also consistent with HAOT being parental to both suites of evolved magmas.

\subsection{High-Alumina Olivine Tholeiite-The Tholeiitic Suite}

[13] Western Harney Basin high-alumina olivine tholeiite (HAOT) comprises basalt compositions (47-50 wt.\% $\mathrm{SiO}_{2}$ ) with more than 16 wt. $\% \mathrm{Al}_{2} \mathrm{O}_{3}$ and $\mathrm{MgO}$ variation from 7 to $10.5 \mathrm{wt} . \%$ that decreases with increasing $\mathrm{FeO}^{*}$ ( 9 to 12 wt.\%) and $\mathrm{TiO}_{2}$ ( 0.7 to 2.0 wt. \%). $\mathrm{K}_{2} \mathrm{O}$ is low (0.2 to $0.6 \mathrm{wt} . \%$, one sample at 0.74), comparable to mid-ocean ridge tholeiites, and $\mathrm{Na}_{2} \mathrm{O}$ ranges from 1.95 to $3.4 \mathrm{wt} . \%$ (Figures 3 and 4 and Table 1). We use the term HAOT to describe the high-alumina character of these olivine tholeiites, which closely matches the 

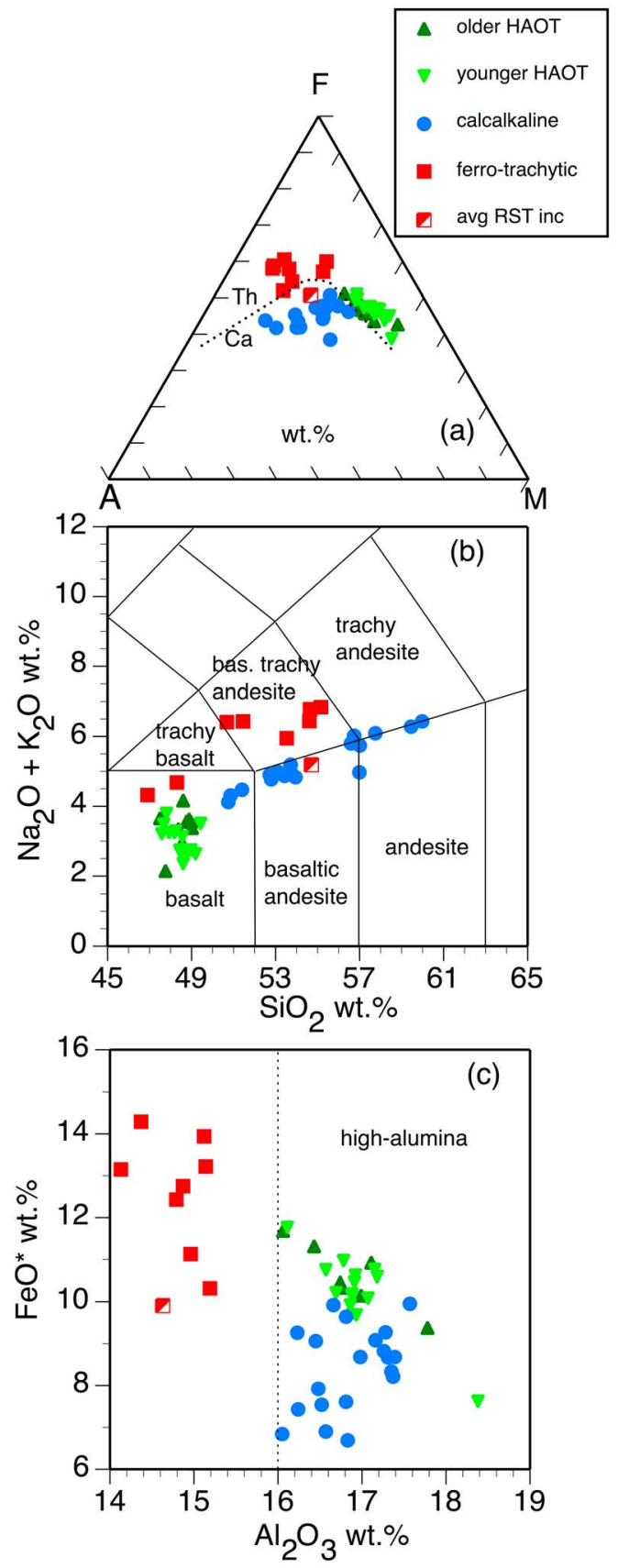

Figure 3. Classification of Harney Basin basaltic and andesitic rocks using the AFM diagram [Irvine and Baragar, 1971], total alkalis-silica diagram of Le Bas et al. [1986], and a $\mathrm{FeO} *$ versus $\mathrm{Al}_{2} \mathrm{O}_{3}$ variation diagram.

HAOT as defined by Hart et al. [1984] and also Hart [1985]. We include, however, compositions that are slightly richer in $\mathrm{K}_{2} \mathrm{O}$ and $\mathrm{TiO}_{2}$ which in the nomenclature of Hart et al. [1984] would fall into other subcategories of regional tholeiites such as low-K, low-Ti transitional tholeiites (LKLT), low-K, high-Ti transitional tholeiites (LKHT), and high-K,
high-Ti or Snake River tholeiites (SROT). We prefer the factual usage of the term HAOT because the entire range of tholeiites of this study occur within a small area far from the Snake River Plain, Idaho. Variation of composition among tholeiites is observed even within single conformable stacks of lavas and so we prefer not to assign them names with larger geographic association. Trace elements characteristics of HAOT lavas are essentially identical to previous studies [Hart et al., 1984; Hart, 1985; Draper, 1991; Bailey and Conrey, 1992] but, like K, also grade toward slightly higher incompatible trace element concentrations (Table 1 and Figure 4; i.e., $\mathrm{Rb}-1$ to $8, \mathrm{Ba}-65$ to 514 , and $\mathrm{La}-2$ to $16 \mathrm{ppm})$.

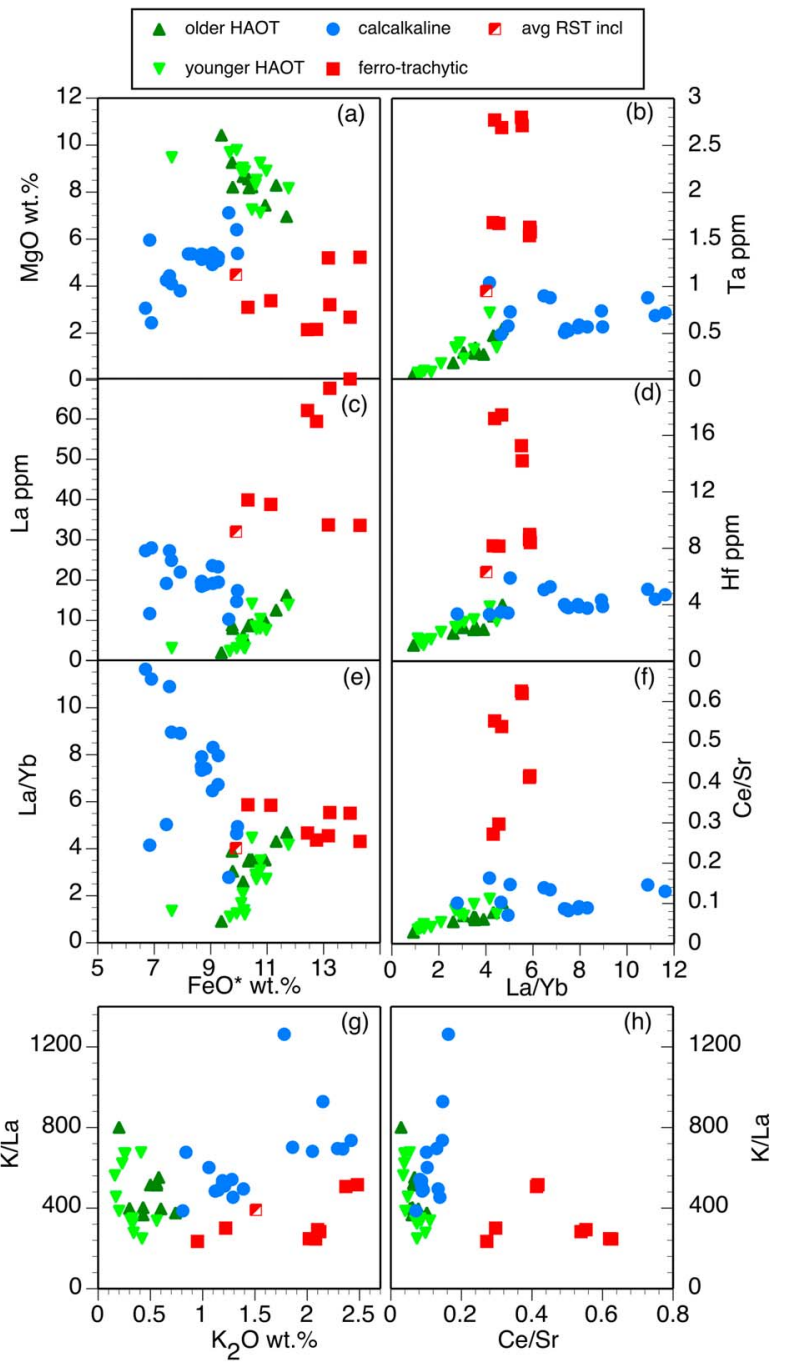

Figure 4. Scatter diagrams of Harney Basin basaltic suites showing progressively chemical trends within individual suites, among suites, and strong compositional divergent between calcalkaline and ferro-trachytic suite starting at the incompatible trace element enriched end of the HAOT suite. 

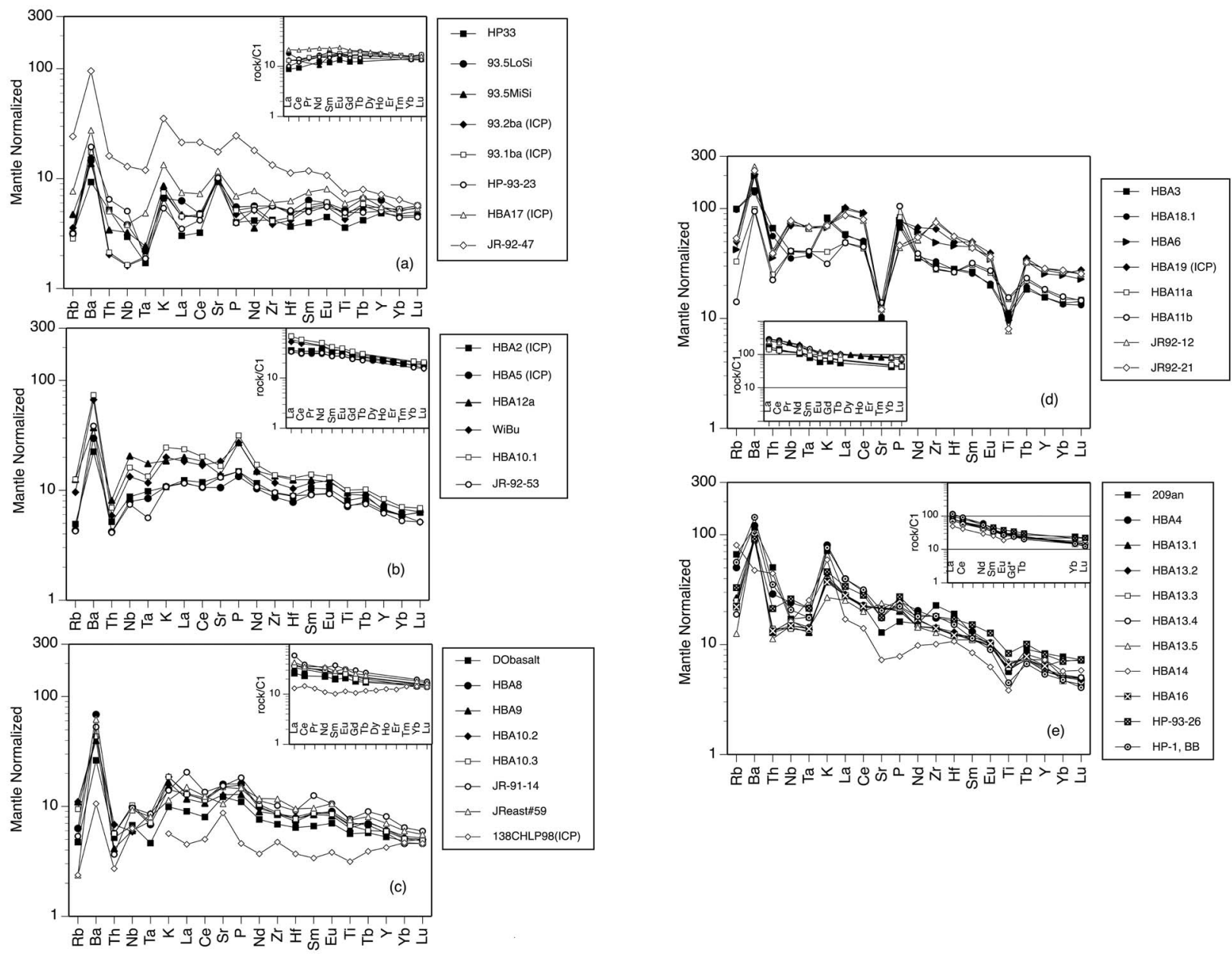

Figure 5. Mantle normalization plots and REE diagrams for Harney Basin basaltic suite; (a-c) for HAOT samples, (d) for ferro-trachyitic, and (e) for calcalkaline samples. Mantle composition was taken from Sun and McDonough [1989] and C1 chonditic values from McDonough and Sun [1995]. Value for Gd is interpolated between Sm and $\mathrm{Tb}$ where not available; (ICP) indicates samples with ICP-MS trace element data.

Within the spectrum of our HAOT compositions, we refer to depleted HAOT and enriched HAOT based on the degree of incompatible element enrichment. There is a subtle difference between the older and the younger HAOT, where the older are, overall, slightly more enriched in $\mathrm{K}, \mathrm{Hf}, \mathrm{Ta}, \mathrm{Ce} / \mathrm{Sr}$, and $\mathrm{K} / \mathrm{La}$ (Figure 3).

[14] In general, decrease in $\mathrm{MgO}$ is associated with decreases in $\mathrm{Cr}$ and $\mathrm{Ni}$, and increases in $\mathrm{K}_{2} \mathrm{O}$, and incompatible trace elements (Figure 2 and Table 1). Unlike Hart et al. [1984], we do not find consistent mineralogical changes associated with the transition from depleted to enriched HAOT. All HAOT range from aphyric to bearing $10 \%$ phenocrysts of olivine or occasional glomerocrysts of olivine and plagioclase. Individual phenocrysts of plagioclase have only been observed in a few enriched HAOT. Groundmass is diktytaxitic to ophitic consisting of olivine, orthopyroxene, clinopyroxene, plagioclase, and Ti-magnetite.

[15] Some trace element characteristics of HAOT from the western Harney Basin are MORB-like ( $\mathrm{T}$ to E-MORB) while others are distinctly different, resembling volcanic arc related basalts [Hart et al., 1984; Hart, 1985; Draper, 1991; Bailey and Conrey, 1992]. MORB-like features include overall flat to slightly depleted trace element patterns (depleted samples) (Figure 5a). Mantle normalized patterns typically become more concave upward as incompatible trace element concentrations increase; highest are values mainly from $\mathrm{K}$ to $\mathrm{La}$, except $\mathrm{Ba}$, which has a spike (Figures $5 \mathrm{~b}$ and $5 \mathrm{c}$ ). A characteristic feature of all HAOT samples is the great enrichment of $\mathrm{Ba}$ relative to neighboring $\mathrm{Rb}$, $\mathrm{Th}$, and high-field strength elements (HFSE) (Figure 5), even with consideration of analytical precision at 
low concentrations of $\mathrm{Rb}, \mathrm{Th}$ and $\mathrm{Nb}$. A subtle, but persistent feature among all HAOT samples is a slight trough in Ti compared to neighboring elements (Figure 5). $\mathrm{Tb} / \mathrm{TiO}_{2}$ ratios (unnormalized) of HAOT's are $0.53 \pm 0.08$ and match values of $0.52-$ 0.53 observed in N- to E-MORB [cf. Sun and McDonough, 1989].

[16] Based on commonalities in normalized element diagrams, the western Harney Basin HAOT suite can itself be divided into three categories. One category of HAOT samples have pronounced spikes in $\mathrm{K}$ and $\mathrm{Sr}$ and have troughs in $\mathrm{Nb}$ and $\mathrm{Ta}$; normalized $\mathrm{Th}$ values are near those of $\mathrm{Nb}$ and $\mathrm{Ta}$ (Figure 5a). We group sample JR-92-47 with this category because of similarity of its trace element pattern, although its overall concentrations are high and it has no Sr spike. A second category includes samples with a spike in $\mathrm{P}$, virtually no or very small HFSE anomalies and with normalized Th values near or below those of $\mathrm{Rb}$. Normalized Th values of these samples are lower than $\mathrm{Nb}$ and $\mathrm{Ta}$, leading to a trough in Th (Figure 5b). A K spike is weak or absent. The third category contains all other samples that have no or small spikes in either $\mathrm{K}, \mathrm{Sr}$, or $\mathrm{P}$ and are otherwise transitional between the earlier categories (Figure 5c).

[17] The large scale features of these troughs and spikes that allow assignment of categories are not artifacts of low analytical precision at low concentrations. The patterns repeat over a range of concentrations. Furthermore, some of these characteristics reappear in normalized element patterns of the calc-alkaline and the ferrobasalt -trachyandesite suite, which have substantially higher overall concentrations. And finally, the patterns are confirmed by re-analysis of select samples (Figure 6a, Table S2, and Figure S1).

\subsection{Calcalkaline Basalt to Andesite-The Calcalkaline Suite}

[18] Calcalkaline lavas range from 51 to $60 \mathrm{wt} \%$ $\mathrm{SiO}_{2}$ and have $\mathrm{Al}_{2} \mathrm{O}_{3}$ concentrations ranging from 16 to $17.6 \mathrm{wt} . \%$, which overlaps the range of HAOT. Calcalkaline lavas are discriminated from HAOT on the AFM diagram (Figure 3a) and also have the lowest overall concentrations in $\mathrm{FeO}^{*}$, from $\sim 10$ to $\sim 6 \mathrm{wt} . \%$ (Figure $3 \mathrm{c}$ ). The three basaltic samples are transitional to tholeiite in a $\mathrm{Fe} / \mathrm{Mg}$ versus $\mathrm{SiO}_{2}$ diagram, but we group them with the calcalkaline samples because of their higher $\mathrm{K}_{2} \mathrm{O}$ content (0.81-1.1 wt.\%). In terms of total alkalis, the Harney Basin calcalkaline suite straddles the subalkaline/alkaline divide (Figure 3). Mafic samples of the calcalkaline suite fall in the middle of the medium K field of Le Bas et al. [1986] and trend toward the high-K field with compositions above $56 \mathrm{wt} \% \mathrm{SiO}_{2}$ plotting close to the medium/high-K boundary. Lavas are all sparsely phyric with phenocryst contents of $1-2 \%$ or less. Phenocrysts are plagioclase and to a lesser extent olivine or pyroxene and are typically smaller than $\sim 300 \mu \mathrm{m}$. Groundmass crystals are finer than those observed in HAOT and textures can be trachytic.

[19] Incompatible trace elements concentrations increase variably with increasing $\mathrm{SiO}_{2}$ and decreasing $\mathrm{FeO}^{*}$ (cf. Figures 3 and 4). As much as fourfold enrichment is observed in most LILE elements such as $\mathrm{Rb}$, Th, and $\mathrm{U}$; moderate enrichments (2- threefold) are observed for $\mathrm{Ba}$ and $\mathrm{La}$ and $\mathrm{Ce}$. On the other hand, enrichments in HFSE trace elements $(\mathrm{Zr}, \mathrm{Hf}$, $\mathrm{Ta}, \mathrm{Nb}$ ) are typically less than twofold (Figure 4) and are non-systematic with major element variation. HREE concentrations and $\mathrm{Y}$ increase less than 1.5 fold defining sub-horizontal trends when plotted against $\mathrm{SiO}_{2}$ or $\mathrm{MgO}$. Consequently, REE patterns become progressively steeper with decreasing $\mathrm{FeO}^{*}$; $\mathrm{La} / \mathrm{Yb}$ increases from $\sim 4$ in mafic samples to $\sim 12$ in andesite (e.g., Figure 4f).

[20] Like in the HAOT suite, calcalkaline samples have a pronounced $\mathrm{Ba}$ spike in mantle normalized element diagrams (Figure 5e). Because $\mathrm{Rb}$ and $\mathrm{Th}$ increase more compared to $\mathrm{Ba}$, the $\mathrm{Ba}$ spike becomes progressively smaller toward higher $\mathrm{SiO}_{2}$. $\mathrm{Ba} / \mathrm{Rb}$ is $\sim 50$ at the mafic end and 28 or less at the silicic end of the suite. HFSE anomalies relative to $\mathrm{K}$ and La are small and $\mathrm{K}$ makes a spike, as documented for some HAOT samples. The intensity of the K spike and of HFSE troughs generally increase with evolution as corroborated by positive correlation of $\mathrm{K} / \mathrm{La}$ and $\mathrm{K} / \mathrm{Ta}$, and of $\mathrm{La} / \mathrm{Ta}$ with $\mathrm{SiO}_{2}$. A few samples have unusual compositional features such as sample HBA14 that has high $\mathrm{Cr}$ and $\mathrm{Mg}$ concentrations combined with high $\mathrm{Rb}$ and $\mathrm{SiO}_{2}$.

\subsection{Ferrobasalt and Trachyandesite- The Ferro-trachytic Suite}

[21] Lavas of the ferro-trachytic suite are phenocryst poor $(\leq 1 \%)$. Sparse phenocrysts are mainly plagioclase and clinopyroxene. Plagioclase ranges from strongly resorbed with sieve textures to euhedral. Lavas from Paiute Butte (JR-92-12, -21, Table 1) contain $\mathrm{Fo}_{34}$ olivine phenocrysts and conspicuous apatite [Maclean, 1994]. Magma compositions fall along a tholeiitic differentiation trend and all have FeO* above 12 wt.\% and $\mathrm{TiO}_{2}$ values between 1.7 to $3.3 \mathrm{wt} \% \%$ (Figure 3), except lavas of the $5.44-\mathrm{Ma}$ 
vent (HBA 3, HBA18.1-6) and mafic inclusions in the Rattlesnake Tuff. $\mathrm{SiO}_{2}$ values range from 47 to 55 wt. $\% . \mathrm{Al}_{2} \mathrm{O}_{3}$ ranges from 14 to $15 \mathrm{wt} . \%$ and is considerably lower than in either the HAOT or calcalkaline suites. A characteristic feature of the ferrotrachytic suite is high $\mathrm{P}_{2} \mathrm{O}_{5}$ with concentrations of 1 to 2 wt.\%. High $\mathrm{P}_{2} \mathrm{O}_{5}$ is a common feature not only among Fe-enriched basaltic magmas of the High Lava Plains but elsewhere (see discussion below). In particular, ferrobasalt HBA11a \& b is almost indistinguishable from phosphorous-rich ferrobasalts of Craters of the Moon, a young volcanic field along the Snake River Plain in Idaho [Leeman et al., 1976].

[22] In addition to their distinctive major element compositions, samples of the ferro-trachytic suite are characterized by great enrichments of incompatible elements (Figures 4 and 5d), which are stronger in trachyandesites than in ferrobasalt. Enrichment factors for the suite relative to enriched HAOT are 4 to sixfold in HFSE elements, all REE elements, and LILE elements except Sr. For example, $\mathrm{Zr}$ reaches concentrations as high as $800 \mathrm{ppm}$, $\mathrm{La}$ to $68 \mathrm{ppm}, \mathrm{Ba}$ to $1600 \mathrm{ppm}$, and Ta to $2.8 \mathrm{ppm}$ (Table 1 and Figure 4). Overall steepness of REE patterns of ferrobasalts and trachyandesites $(\mathrm{La} / \mathrm{Yb}$ 4-6) is essentially the same as that of enriched HAOT lavas ( $\mathrm{La} / \mathrm{Yb} 4-4.5)$ (Figure 5).

[23] A Ba spike is present in all samples of the ferro-trachytic suite and normalized $\mathrm{Th}$ and $\mathrm{Rb}$ values are lower than $\mathrm{Nb}$ and $\mathrm{Ta}$ values except for samples of the 5.44-Ma vent where $\mathrm{Rb}$, Th and $\mathrm{K}$ have systematics like those of calcalkaline basaltic andesites/andesites (Figure 5d). A P spike is present in the ferrobasalt samples, but declines in enriched trachyandesite (HBA6 \& 19). A P trough (relative to $\mathrm{Ce}$ and $\mathrm{Nd}$ ) is indicated in the most silicic and enriched trachyandesites (JR-92-12, -21) consistent with apatite fractionation (Figure $5 \mathrm{~d}$ ).

[24] Other pronounced features in all normalized patterns of this group include troughs in $\mathrm{Sr}$ and $\mathrm{Ti}$, that are mostly stronger than in the calc-alkaline suite; $\mathrm{Ce} / \mathrm{Sr}$ ranges from 0.25 to 0.6 among ferrotrachytic samples, compared to $\sim 0.1$ in calcalkaline samples and 0.01-0.1 in HAOT lavas (Figure 4). Similarly, $\mathrm{Tb} / \mathrm{TiO}{ }_{2}$ ratios can be used to track the $\mathrm{Ti}$ trough; $\mathrm{Tb} / \mathrm{TiO}_{2}$ ranges between 0.7 to 2.1 in this suite, 0.5 to 0.95 in the calcalkaline suite and is $0.5 \pm 0.1$ in all HAOT samples.

[25] Mafic inclusions found in the Rattlesnake Tuff, and that are hosted by dacitic pumices, are compositionally akin to those of $\mathrm{Fe}$-rich trachyandesites but typically are less enriched in $\mathrm{Fe}$ and incompatible elements, which makes them transitional to calcalkaline samples and (Figures 3 and 4) [Streck and Grunder, 1999] similar to the other transitional samples of the 5.44-Ma vent (HBA 3, HBA 18.118.6, Table 1) where $\mathrm{FeO}^{*}$ remains relatively low, with a small $\mathrm{K}$ peak (Figure 5d). However, high $\mathrm{P}_{2} \mathrm{O}_{5}$, high $\mathrm{TiO}_{2}$, low $\mathrm{La} / \mathrm{Yb}$, among other criteria, group Rattlesnake Tuff inclusions and samples of 5.44-Ma vent with the ferro-trachytic sub-suite.

\section{Discussion}

[26] The Harney Basin mafic suite overall is distinctly divided into three trends: the tholeiitic (HAOT) suite, the calcalkaline suite and the ferrotrachytic suite (Figure 3). We here consider the origin of the variability within each suite and then consider the relationships between suites and the implications for changes in magma evolution processes over time. We take primitive HAOT samples to represent the parental magma from which the tholeiitic suite is derived. Evolved HAOT, in turn, we test as the composition that engenders the calcalkaline and the ferro-trachytic suites (Figure 4). While HAOT compositions occur throughout the history of western Harney Basin volcanism, calcalkaline compositions occur close in time to eruption of voluminous rhyolites indicated by the Rattlesnake and Buckaroo Lake ignimbrites (7.1 and $6.85 \mathrm{Ma}$ ). Volcanic rocks of the ferro-trachytic suite, on the other hand, erupted mostly late in the eruptive sequence, after protracted mafic magmatism and after the main calcalkaline activity, albeit ferro-trachytic mafic inclusions occur in the Rattlesnake Tuff. Before considering the liquid lines of descent and potential temporal feedbacks affecting them, we consider how much of the variability among primitive HAOT might be attributable to mantle conditions.

\subsection{Variability Among High-MgO HAOT Imparted in the Mantle}

[27] We examine the high-MgO HAOT to consider mantle source effects on the basalts of the western Harney Basin. These have MgO 10.4-8 wt.\%, Mg number $67-55, \mathrm{Cr} 244-178 \mathrm{ppm}$, and Ni 20599 ppm (Table 1). Among these high-Mg HAOT, $\mathrm{MgO}$ covaries with $\mathrm{Mg} \#\left(\mathrm{R}^{2}=0.86\right)$ and to a lesser degree with $\mathrm{Cr}\left(\mathrm{R}^{2}=0.37\right), \mathrm{Ni}\left(\mathrm{R}^{2}=0.47\right)$. Ni and $\mathrm{Cr}$ in turn covary with $\mathrm{R}^{2}=0.49$. Compositional variation cannot be ascribed to crystal accumulation, because all of the high-Mg HAOT are phenocrystpoor to aphyric. The high-Mg HAOT have compositions close to a mantle-equilibrated melt 
based on comparison to primitive HAOT from Medicine Lake Volcano determined to be in equilibrium with a spinel lherzolite at $1100 \mathrm{MPa}$ [Bartels et al., 1991] and HAOT from nearby Diamond Craters that equilibrated with spinel lherzolite at $1100 \mathrm{MPa}$ [Till, 2011]. These pressures are consistent with melt derivation from just beneath the Moho, which is at about $38 \mathrm{~km}$ under the Harney Basin [Catchings and Mooney, 1988; Eagar et al., 2011].

\subsubsection{Variable Melting}

[28] Variation in the degree of mantle melting is only a minor contributor to the range in composition of high-Mg HAOT of the Harney Basin. We calculate that no more than $\sim 30 \%$ of the variation in trace elements among the high-Mg HAOT may be attributable to varying degrees of partial melting of a spinel lherzolite source, where incompatible element concentrations will be controlled primarily by clinopyroxene.

[29] We use a simple equilibrium melting model in which the partition coefficients of garnet and clinopyroxene control the key elements $\mathrm{La}, \mathrm{Yb}, \mathrm{Hf}$, and $\mathrm{Ta}$, as well as $\mathrm{K}$ and $\mathrm{Na}$, to place an upper bound on how much elemental variability might be attributed to variable degrees of melting of a garnet or spinel lherzolite (Figure 7). Addition of other common mantle phases would reduce the partition coefficients. We take one depleted HAOT (\#93.1ba) (Table 1) to represent the largest degree of melt, as it is among the samples with the lowest $\mathrm{La}$ and highest $\mathrm{MgO}$ concentrations. We assume $12 \%$ melt for this sample, as $12 \%$ likely corresponds to the lower melting percent at which tholeiitic magmas are produced [cf. Hirose and Kushiro, 1993]. With that, we calculated models to explore scenarios of how melt composition changes with changes in melt percentage (Figure 7). No clinopyroxene-dominated melting model, even at very small degrees of melting, can account for the trace element and alkali variations in the high-MgO HAOT. While a garnet-source melting model is theoretically promising with respect to $\mathrm{Hf} / \mathrm{Ta}$ compared to $\mathrm{La} / \mathrm{Yb}$ (Figure 7a), it still predicts far greater alkali enrichment than observed (Figure 7b). Assuming a higher degree melt for the depleted HAOT won't change these principal findings.

[30] Neither can fractional melting account for the variation in incompatible elements because $\mathrm{K} / \mathrm{La}$ decreases with higher $\mathrm{K}_{2} \mathrm{O}$ concentrations (Figure $4 \mathrm{~g}$ ). Less melting would induce the opposite, enriching the more incompatible $\mathrm{K}$ relative to La [e.g., Zou and Reid, 2001]. Similarly, a model of elemental exchange during melt migration through peridotite [Kelemen, 1990] cannot account for observed patterns of incompatible elements in high-Mg HAOT. Therefore, the elemental variation among high-Mg HAOT is not primarily the result of variable partial melting processes. We estimate the potential contribution by variable partial melting to be limited to within the concentration range of sample 93.1 ba to HBA17, which accounts to $\sim 1 / 3$ of the data array of Figure 7 and to $\sim 1 / 4$ of the incompatible element range among HAOT samples. We use these two samples because they have virtually identical normalized trace element patterns, yet HBA17 indicates slight enrichment compared to 93.1ba (Figure 6 and Table 1).

\subsubsection{Crystal Fractionation}

[31] A small amount of fractionation could account for $100 \mathrm{ppm} \mathrm{Ni}$ decrease from 10.5 to $\sim 8 \mathrm{wt} \%$ $\mathrm{MgO}\left(7 \%\right.$ crystal removal using $\mathrm{D}_{\mathrm{Ni}}$ for olivine of $10)$, which would barely affect La concentrations. Enrichment of La to as great as $14 \mathrm{ppm}$, starting with a parent having 2 ppm, would require more than 90\% crystallization, even assuming La is perfectly incompatible. No realistic single stage crystal fractionation model can account for incompatible element variations among the high-MgO HAOT samples. We attribute most of the variability among the high-Mg HAOT to the same processes that generates variability in the rest of the HAOT suite, namely crystal fractionation in combination with open systems processes in the form of assimilation of incompatible enriched material and/or of mixing with highly evolved basaltic magmas. Before turning to that discussion we complete an assessment of the mantle reservoir.

\subsubsection{Mantle Source Variability}

[32] Western Harney Basin Sr-, Nd-, and Pb-isotopes signatures of HAOT basalts correspond well with geographic trends of $\sim 12-0$-Ma HAOT in the High Lava Plains reflecting a more enriched mantle source to the east [Hart, 1985; Carlson and Hart, 1987; Jordan, 2001], and are possibly mixtures of a depleted mantle source and a re-enriched depleted mantle source, as proposed by Carlson [1984] (Figure 8). They also overlap with the character of contemporaneous low-K tholeiites (aka HAOT) from the Cascade volcanic range [Bacon et al., 1997; Conrey et al., 1997; Schmidt et al., 2008], which also are dominantly derived from a depleted mantle 

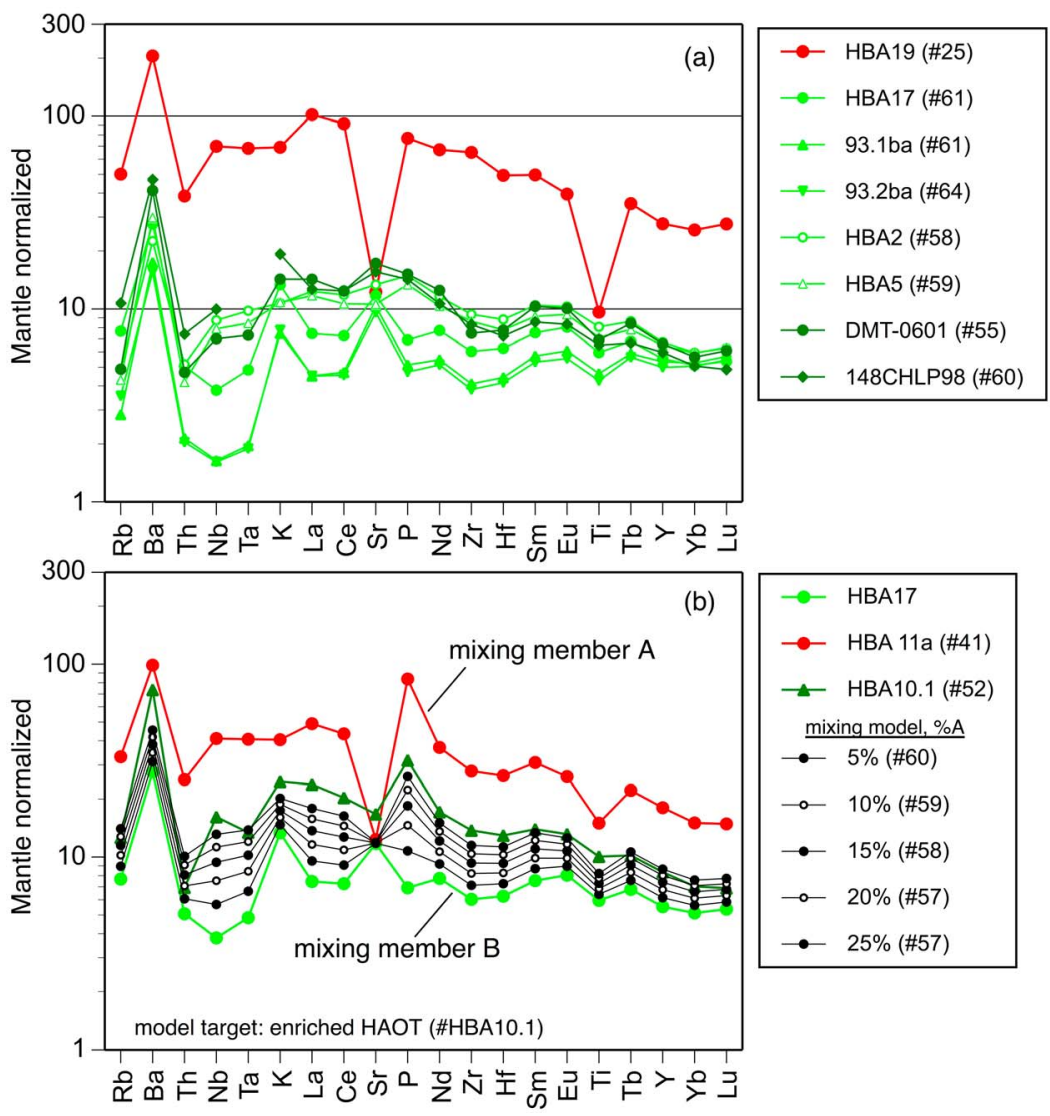

Figure 6. (a) Mantle normalization for select Harney Basin basaltic rocks with ICP-MS data and (b) mixing model calculation between enriched sample HBA11a of ferro-trachytic suite with HAOT sample HBA17. Number in parenthesis after sample number is $\mathrm{Mg} \#\left(\right.$ molar $\left.\mathrm{Mg} /\left(\mathrm{Mg}+\mathrm{Fe}^{*}\right) \times 100\right)$. Mantle composition was taken from Sun and McDonough [1989].

source that was subsequently re-enriched by (potentially Paleogene) subduction processes [e.g., Borg et al., 2002; Leeman et al., 2005]. Helium isotope data do not point to any significant involvement of a plume source [Graham et al., 2009].

[33] Western Harney Basin basalt data are generally consistent with a temporal pattern of basalt derivation from a more depleted mantle in time across the High Lava Plains. Jordan [2001] observed that the Quaternary and Pliocene primitive basalts have more isotopically depleted mantle signatures than those of Late Miocene basalts, in the central and western High Lava Plains, west of the Harney Basin (Figure 8); to the east of Harney Basin, the reverse is true. Nevertheless, we assume an essentially isotopically uniform mantle source beneath the western Harney Basin, which is supported by close similarity in $\mathrm{Sr}-, \mathrm{Nd}$ - and $\mathrm{Pb}$-isotopic character among three basalts spanning from 7.5 to about $6 \mathrm{Ma}$ (93.1 ba and JR-92-53, Table 1; 148CHLP98 [Jordan, 2001]; Figure 8). The young, 2.9-Ma and westernmost basalt at the immediate periphery of the western Harney Basin yields the lowest $\mathrm{Sr}$ and highest $\mathrm{Nd}$ isotopic signature, and indeed the whole High Lava Plains (\#138CHLP98 [Jordan, 2001]).

[34] Slightly higher Sr- and lower Nd-isotope ratios are found in one calcalkaline andesite (209an) and in a quenched basaltic andesitic inclusion of the Rattlesnake Tuff [cf. Streck and Grunder, 2008], consistent with a modest amount of crustal contamination. The most enriched trachyandesite (JR-92-21) has isotopic compositions indistinguishable from HAOT.

[35] While there is agreement that the mantle source is depleted, akin to a MORB source, the relative enrichments in $\mathrm{Ba}, \mathrm{Pb}$ and $\mathrm{Sr}$ have been the main argument for a subduction component, that is modern or ancient, and possibly even an OIB-like component [Carlson, 1984; Hart, 1985; Brandon et al., 1993; Conrey et al., 1997; Bacon et al., 1997; Borg et al., 2002; Jordan et al., 2002]. We here test for the presence and proportion of enrichment with 
OIB- and subduction components in our basalt suite.

[36] A distinctive feature of high-Mg (primitive) HAOT is that the REE patterns vary from nearly flat at ten-times chondritic values to about 50 times enriched in LREE (Figure 5); $\mathrm{La} / \mathrm{Yb}$ increases from 0.9 to 4.4 with $\mathrm{K}_{2} \mathrm{O}$ increase from 0.2 to $\sim 0.7$ wt.\% and total alkalis from 2.2 to $3.8 \mathrm{wt} . \%$ (Figure 6). This enrichment is not owing to involvement of an OIB component, as variation of $\mathrm{Ce} / \mathrm{P}$ with $\mathrm{La} / \mathrm{Yb}$ (Figure 8c) points away from typical OIB [Sun and McDonough, 1989] and plot far from basalts with OIB-like, high-field strength element enriched signatures in the arc [Leeman et al., 2005]. Element ratios such as $\mathrm{Sr} / \mathrm{P}$ and $\mathrm{Ba} / \mathrm{Ta}$, which are thought to track a subduction component [e.g., Borg et al., 2002] correlate either negatively (Figures $9 a$ and $9 b$ ) or hardly at all (Figures 9c and 9d) with $\mathrm{La} / \mathrm{Yb}$ and $\mathrm{K}_{2} \mathrm{O}$. Sr/P suggests the opposite, namely that the highest degree melt (lowest $\mathrm{La} / \mathrm{Yb}$ and $\mathrm{K}_{2} \mathrm{O}$ ) and (or) most depleted mantle source carries the strongest subduction component signature (highest $\mathrm{Sr} / \mathrm{P}$ ).

[37] On the other hand, we can identify some trace element variability that is likely to have existed in the mantle beneath the western Harney Basin as indicated by the relative amount of Th (and to a lesser degree of $\mathrm{Rb}$ ) relative to $\mathrm{Nb}$ and $\mathrm{Ta}$. One mantle composition gave rise to HAOT with normalized Th values that are about equal to $\mathrm{Nb}$ and Ta (Figure 6); the other gave rise to samples with a Th trough with normalized values of Th less than $\mathrm{Nb}$ and Ta. Although one is tempted to associate other differences in normalized trace element patterns of HAOT as noted above (cf. Figures $5 \mathrm{a}$ and $5 b)$ to differences in original mantle composition, we do not think this is warranted. We base this on a simple mixing model of HAOT with $\mathrm{K}$ and $\mathrm{Sr}$ spikes and lacking a $\mathrm{P}$ spike (i.e., Figure 5a normalized patterns) with an enriched ferrotrachytic sample, which effectively produces patterns without K or Sr spikes, but with P spike (i.e., Figure 5b patterns). Differences in Th of Harney Basin mantle does not correlate with even small changes in isotopes as samples (93.1ba and JR92-12) with the same isotope ratios carry either Th feature (cf. Figures 6 and 8).

[38] In summary, high-Mg HAOT magmas are derived from a regional mantle reservoir of depleted mantle overprinted with a subduction component [cf. Hart, 1985] and that did not change much in time. The variation among the high-Mg HAOT was modestly influenced by the degree of partial melting and is not influenced by variable contribution of an OIB or subduction signature. Very low $\mathrm{Rb}$ and $\mathrm{Th}$ and variation in $\mathrm{Th}$ relative to $\mathrm{Nb}$, Ta are intriguing and may suggest either multiple depletion events or variation in degree of mantle depletion. Most of the variation cannot be attributed to mantle variations and, like the variation in the rest of the HAOT suite, results from differentiation processes in the crust.

\subsection{HAOT Liquid Line of Descent}

[39] Four characteristics are diagnostic with differentiation: 1) a mafic bulk composition with $\mathrm{MgO}$ decrease and $\mathrm{FeO}^{*}$ increase; 2) an overall increase in concentration of incompatible elements; 3) small, but increasing LREE enrichment; and 4) enrichment in phosphorous.

\subsubsection{Mafic Bulk Composition}

[40] $\mathrm{MgO}$ varies from near 10.5 to a little under 7 weight $\%$ in the HAOT suite, while silica varies little and $\mathrm{FeO}^{*}$ increases from a little over 9 to 12 weight $\%$ (Table 1). This overall mafic character is consistent with as much as $60-70 \%$ crystal fractionation from the most magnesian primitive composition (HP-33) under conditions from dry to 0.5 weight percent water and oxygen fugacity at the fayalite-magnetite-quartz buffer, based on dozens of models using the Melts code [Ghiorso and Sack, 1995]. A simple model of polybaric crystallization of HP-33 from near the Moho at 1.1 GPa to $0.1 \mathrm{GPa}$ and from 1300 to $1200^{\circ} \mathrm{C}$ produces an excellent match to 93.1ba (sum of residuals $^{2}=0.02$ ) at conditions of FMQ and 0.2 weight percent water in the parent with $65 \%$ minerals removed. Although using sample $93.1 \mathrm{ba}$ as model target does not represent the full range in HAOT compositions, we chose this range to highlight principal controls on fractionation models. This polybaric scenario balances the advantages of deep and shallow crustal crystallization. In the deep crust, clinopyroxene fractionation keeps $\mathrm{Al}_{2} \mathrm{O}_{3}$ high and does not decrease $\mathrm{MgO}$ too rapidly, as would olivine, and in the shallow crust the olivineplagioclase assemblage suppresses $\mathrm{Al}_{2} \mathrm{O}_{3}$ excess. FMQ conditions suppress Fe-Ti oxide precipitation and attendant $\mathrm{SiO}_{2}$ increase and $\mathrm{FeO}^{*}$ decrease, and a modest amount of water suppresses onset of plagioclase precipitation.

[41] Most HAOT have $\mathrm{K}_{2} \mathrm{O}$ and incompatible trace elements concentrations too high to be the product of simple crystal fractionation, and $\mathrm{P}_{2} \mathrm{O}_{5}$ is particularly high. 


\subsubsection{Multifold Incompatible Element Enrichments and Steepening Tilts in HAOT's}

[42] The combination of mafic, but fractionated bulk composition with high enrichment levels of incompatible elements can be achieved if one calls upon: i) contamination coupled with fractionation, ii) cycles of combined fractionation and magmatic recharge with a mafic (the parent) composition [O'Hara and Mathews, 1981; Spera and Bohrson, 2004], or iii) mixing with a strongly differentiated mafic magma. Multifold enrichments are easily achievable by repeated fractionation for highly incompatible elements while compatible elements have limited depletion owing to recharge [Wiebe et al., 1997; Streck and Grunder, 1999]. While recharge has a role to play (see ferro-trachytic suite), the subtle but distinct steepening of the REE
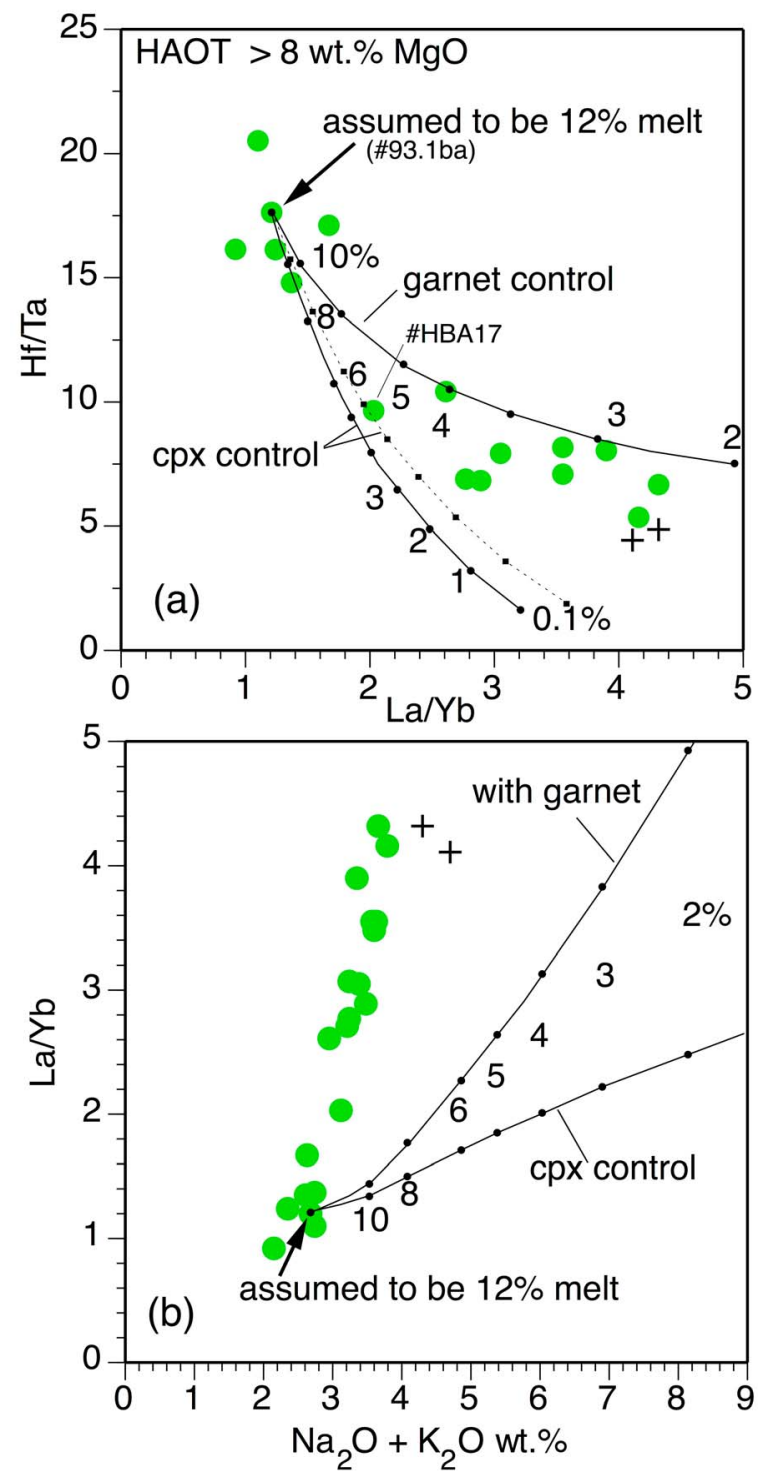

pattern (La/Yb from 0.9 to 4.7$)$ in the tholeiitic suite with decreasing $\mathrm{MgO}, \mathrm{Cr}$ and $\mathrm{Ni}$ and increasing total $\mathrm{Fe}$ and alkalis (Figures 3, 4, and 7) cannot be accounted for by repeated fractionation of the same mineral assemblage. If we ascribe $\sim 30 \%$ of this tilt to variable degrees of mantle melting corresponding to a change in melting degree by $\sim 6$ to $7 \%$ for garnet versus cpx control, respectively (cf. Figure 7) then $70 \%$ would need to be imposed by other processes, such as fractionation of minerals that preferentially incorporate HREE or by contamination with a LREE enriched crustal lithology or melt.

[43] Simple fractionation can only increase $\mathrm{La} / \mathrm{Yb}$ to 2.8 with $70 \%$ crystallization $\left(\mathrm{D}_{\mathrm{cpx}}-\mathrm{La} 0.052, \mathrm{Yb}\right.$ 0.63 ) which is the most crystallization a primitive HAOT can sustain and still yield a basaltic daughter based on forward modeling results [cf. Streck and Grunder, 1999]. It is difficult to impose this $\mathrm{La} / \mathrm{Yb}$ increase through recharge and fractionation as it would require extreme clinopyroxene dominated fractionation, which would deplete $\mathrm{Cr}$ long before $\mathrm{La}$ and $\mathrm{La} / \mathrm{Yb}$ enrichments are achievable. Concomitant olivine-plagioclase crystallization would increase the necessary crystallization needed to

Figure 7. Evaluating the control of the degree of melting on compositional spread of high-Mg ( $>8$ wt.\% $\mathrm{MgO}$ ). HAOT samples are solid circles; crosses are for one sample of the ferro-trachytic and calcalkaline suite and are included to show "compositional promixity" of enriched HAOT to members of the calcalkaline (\#HBA13.5) and ferro-trachytic suites (\#HBA11a). Numbers are \% partial melting and curves show calculated model compositions at a given melting percentage relative to one observed composition (sample \#93.1ba, Table 1) assumed to be the product of $12 \%$ partial melting. Model compositions were calculated based on solving two batch melting equations for source composition and setting both equations equal with subsequently solving for one of the melt compositions $\left(\mathrm{C}_{\mathrm{L} 2}\right)$ that is the model composition at a given percent melting. Observed concentrations of sample 93.1ba is $\mathrm{C}_{\mathrm{L} 1}$. (a) Curves: $\mathrm{Hf} / \mathrm{Ta}$ and $\mathrm{La} / \mathrm{Yb}$ are assumed to be solely controlled either by clinopyroxene or by garnet; solid line for cpx based on partition coefficients of Hart and Dunn [1993]; dashed cpx line and solid garnet line based on partition coefficients of Hauri et al. [1994]; all with $\mathrm{D}_{\mathrm{Ta}}=\mathrm{D}_{\mathrm{Nb}} ; \mathrm{D}_{\mathrm{La}}^{\mathrm{cpx}}=0.0536,0.0515 ; \mathrm{D}_{\mathrm{La}}^{\mathrm{ga}}=0.016$; $\mathrm{D}_{\mathrm{Yb}}^{\mathrm{cpx}}=0.43,0.633, \mathrm{D}_{\mathrm{Yb}}^{\mathrm{ga}}=3.88, \mathrm{D}_{\mathrm{Hf}}^{\mathrm{cpx}}=0.256,0.195, \mathrm{D}_{\mathrm{Hf}}^{\mathrm{ga}}=$ $1.22, \mathrm{D}_{\mathrm{Ta}}^{\mathrm{cpx}}=\mathrm{D}_{\mathrm{Nb}}^{\mathrm{cpx}}=0.0077,0.0081, \mathrm{D}_{\mathrm{Ta}-\mathrm{Nb}}^{\mathrm{ga}}=0.0538$ were taken from Hart and Dunn [1993] for cpx and from Hauri et al. [1994] for cpx and garnet. (b) Curves: La/Yb for cpx and garnet as in Figure 7a and total alkali values were calculated with bulk partition coefficients assuming 20\% cpx in the source and cpx partition coefficients for $\mathrm{K}$ of 0.07 [Hauri et al., 1994] and for $\mathrm{Na}$ of 0.25 respectively [Langmuir et al., 1992], all other phases $\mathrm{D}_{\mathrm{K}, \mathrm{Na}}$ assumed 0. 
increase $\mathrm{La} / \mathrm{Yb}\left(\mathrm{La}\right.$ and $\mathrm{Yb}$, respectively: $\mathrm{D}_{\text {oliv }}=$ $0.005,0.04$, and $\left.\mathrm{D}_{\text {plag }}=0.1,0.02\right)$. We think it is more likely that a modest crustal contamination played a role.

[44] There a two possible contamination scenarios that could explain the tilt in REE patterns. One of materials that could serve as contaminant would be crustal analogues to Miocene to Pliocene rhyolites of the region. These have $\mathrm{La} / \mathrm{Yb}$ ratios as high as 15 , but mainly $10-2$, and high REE concentrations, giving them more leverage than compositions as recorded by andesitic and basaltic crustal xenoliths from the Harney Basin, which have $\mathrm{La} / \mathrm{Yb}$ typically below 5 and low REE abundances [Streck, 2002]. More specifically, the leverage of rhyolite in raising $\mathrm{La} / \mathrm{Yb}$ of HAOT's while maintaining a $\mathrm{SiO}_{2}$ composition below $50 \%$ is variable and depends on $\mathrm{La} / \mathrm{Yb}$ and absolute abundances of $\mathrm{La}$ and $\mathrm{Yb}$ of the rhyolite. We found that $5 \%$ of rhyolite contamination (mixing) can raise the $\mathrm{La} / \mathrm{Yb}$ from 2 to 4 while maintaining a HAOT bulk composition. Rhyolitic rocks of the greater Harney Basin are largely products of partial melting with or without subsequent evolution through fractional crystallization [Maclean, 1994; Streck and Grunder, 1997; Streck, 2002; Streck and Grunder, 2008]. Simple mixing with a crustal contaminant is, however, not plausible. Bulk mixing with such contaminants would, for example, pull HAOT samples toward higher $\mathrm{K}_{2} \mathrm{O} / \mathrm{Ta}$ and thus away from the trend defined by depleted to enriched HAOT (Figure 10). Thus, if assimilation were of a silicic material then we favor a combination of fractionation and contamination (an AFC process) as cause for the observed tilt in the REE pattern of HAOT.

[45] Alternatively, the tilt of REE pattern could be caused by the addition of REE enriched material such as apatite when mafic magmas stall, fractionate and interact with crustal rocks (Figure 11). Apatite commonly has a LREE enriched normalized patterns [Belousova et al., 2002; Chu et al., 2009] and would be an effective contaminant even in small quantities given their high REE abundance. Addition of apatite can also explain phosphorous enrichment. We note that modest interaction of similar basalts with a mafic crust was argued on the basis of Os isotope data at Jordan Craters, not far east of the Harney Basin [Hart et al., 1997].

\subsubsection{Phosphorous Enrichment in Tholeiitic Harney Basin Rocks}

[46] High $\mathrm{P}_{2} \mathrm{O}_{5}$ concentrations are common among Fe-enriched, evolved basaltic magmas of the High
Lava Plains, and also more widely in the Pacific Northwest, as well as worldwide (Cascade range [Conrey et al., 2002]; Steens Basalt [Johnson et al., 1998]; Prineville Basalt [Hooper et al., 1993]; Oligocene John Day Formation [Robinson, 1969]; Craters of the Moon in the Snake River Plain, Idaho [Leeman et al., 1976]). Bailey and Conrey [1992] argued that HAOT rocks widespread in the Pacific Northwest are crustally contaminated and attributed high phosphorous to interaction with oxide-apatite rich lower crust. For Icelandic rocks, Eiler et al. [2011] have found a correlation between high $\mathrm{P}$ and low $\partial^{18} \mathrm{O}$ in phenocysts from basalts, also suggesting $\mathrm{P}$ enrichment related to interaction with a mafic crust.

[47] Among Harney Basin HAOT's and ferrobasalts, $\mathrm{P}$ increases with evolution, that is, with decreasing $\mathrm{Mg}, \mathrm{Cr}$, and $\mathrm{Ni}$ and increasing total alkalis and other incompatible trace elements (Table 1). $\mathrm{P}$ is more strongly enriched than neighboring REE and HFSE elements (Figure 5) resulting in P-spikes that we describe in terms of $\mathrm{P} / \mathrm{P}^{*}$ (Figure 11). $\mathrm{P}^{*}$ is the $\mathrm{P}$ concentration derived by interpolation between $\mathrm{Ce}$ and $\mathrm{Nd}$ on normalized element diagrams (Figure 5), analogous to $\mathrm{Eu}^{*}$. We did not use $\mathrm{Sr}$ as the left shoulder value because $\mathrm{Sr}$ itself has spikes and troughs (Figure 5). The strongest $\mathrm{P}$ anomaly is observed in ferrobasalt HBA11 and declines with extreme incompatible element enrichment, as in trachyandesite JR-92-21, owing to apatite fractionation (Figure 11).

[48] Modest overenrichment $(\mathrm{P} / \mathrm{P} *>1)$ among HAOT can be accounted for by as little as $0.8 \%$ assimilation of apatite (Figure 11a, inset), which would affect mainly $\mathrm{P}$ concentrations and to a lesser extent REE concentrations, depending on the REE budget of the apatite (Figure S2). For example, 1\% addition of apatite would add 0.4 wt. $\% \mathrm{P}_{2} \mathrm{O}_{5}$ and 6 ppm Ce versus 35 ppm Ce, using apatite compositions from Pinatubo [Van Hoose, 2011] and Cebolla Creek Tuff [Broderick, 2008], respectively (cf. Figure S2). Ce concentrations within the HAOT range from 6 to $36 \mathrm{ppm}$, but range as high as $160 \mathrm{ppm}$ among ferrotrachytic samples. In other words, while addition of $\mathrm{P}$ from apatite is always significant relative to the amount phosphorous of the basalt magma, the added REE may or may not show strongly (Figure 11). The increasing tilt in the REE pattern observed in the HAOT suite is consistent with addition of suitable apatite (Figures 11 and S2).

[49] We suggest that apatite has been selectively assimilated by HAOT magma rising through crystalline mafic wall rocks bearing apatite and one needs not to rely on the existence of an oxide and 


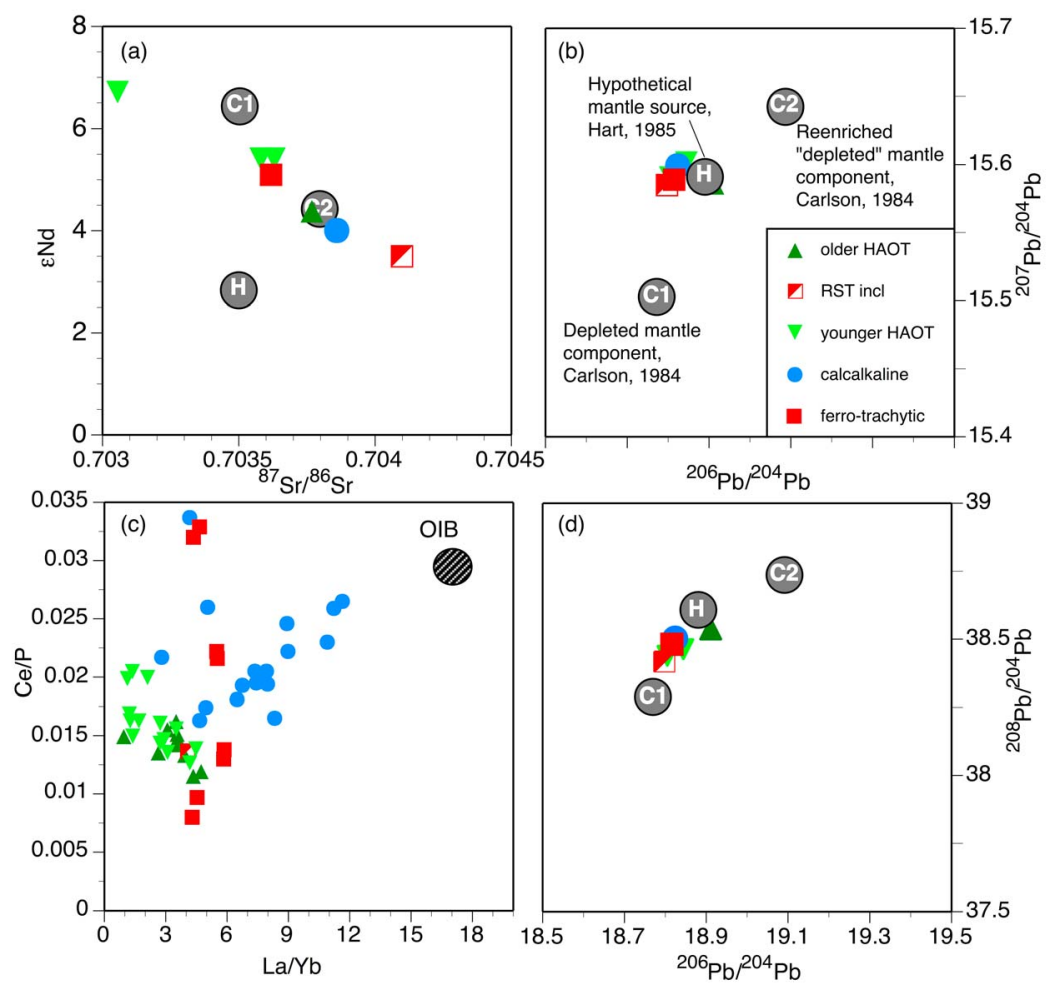

Figure 8. Isotopic data of selected Harney Basin samples suggest that the mantle composition parental to mafic magmas is nearly isotopically invariant and stronger isotopic excursions are only seen in $\mathrm{Nd}$ and $\mathrm{Sr}$ isotopes in one mafic inclusion of the Rattlesnake Tuff; isotopic data are from Streck and Grunder [2008] (younger HAOT samples are \#93.1ba and JR92-53, calcalkaline sample is \#209an, ferro-trachytic sample is JR91-21, and Rattlesnake Tuff mafic inclusion is 210.1b). Samples of older HAOT (\#148CHLP98) and one younger HAOT (\#138CHLP98) at lowest ${ }^{87} \mathrm{Sr}{ }^{86} \mathrm{Sr}$ are from Jordan [2001]. Figure 8c: as La/Yb increases, HAOT compositions trend away from OIB indicating that higher $\mathrm{La} / \mathrm{Yb}$ in enriched HAOT samples does not reflect greater involvement of an OIB-like mantle component, OIB from Sun and McDonough [1989].

apatite-rich lithology [cf. Bailey and Conrey, 1992]. Harney Basin HAOT are much undersaturated in apatite [cf. Toplis et al., 1994]. Apatite saturation temperatures calculated according to Watson and Capobianco [1981] are less than $870^{\circ} \mathrm{C}$, which is well below their expected liquidus temperatures of $\sim 1250$ to $1150^{\circ} \mathrm{C}$. Progressive increase in $\mathrm{P} / \mathrm{P} *$ with total Fe (Figure 11) suggests that assimilation of phosphorous bearing minerals is part of the liquid line of descent from depleted HAOT to ferrobasalt (Figures 8c, 9, and 10b; see discussion above) and was not achieved in a one-stage process. This type of a scenario is to some degree a crustal analogue to that of Kelemen [1990] for reaction of ascending basalt melts with surrounding mantle peridotite. In our case, we envision a dissolution process driven mainly by the degree of undersaturation of basalt magma with respect to apatite and not a melting process, as outlined for apatite in crustal anatexis by Harrison and Watson [1984] and analogous to dissolution AFC modeling of Edwards and Russell [1998]. We don't exclude that other components from the crustal rocks are also mobilized during this assimilation process. However, the point is that REE tilt in HAOT samples and overenrichment of $P$ could be explained together without any effect on differentiation indicators such as $\mathrm{Mg \# \text {. }}$

[50] In the ferrotrachytic suite, the greatest phosphorus overenrichment would require as much as $\sim 3 \%$ apatite assimilation. Ferrobasalt HBA11(a and b) samples yield 1050 and $1080^{\circ} \mathrm{C}$ as apatite saturation temperature, which coupled with groundmass apatite, indicates the magma was close to apatite saturation. Even though this amount seems rather high, that would be the most straightforward explanation for these basaltic samples which also carry other compositional traits indicating significant crustal processing while excluding a direct mantle origin. In fact, we argue below that recharge and fractionation were the main processes at work to achieve high incompatible trace element concentrations in these rocks and emphasize that it is only the overenrichment of $\mathrm{P}$ relative to neighboring incompatible elements 


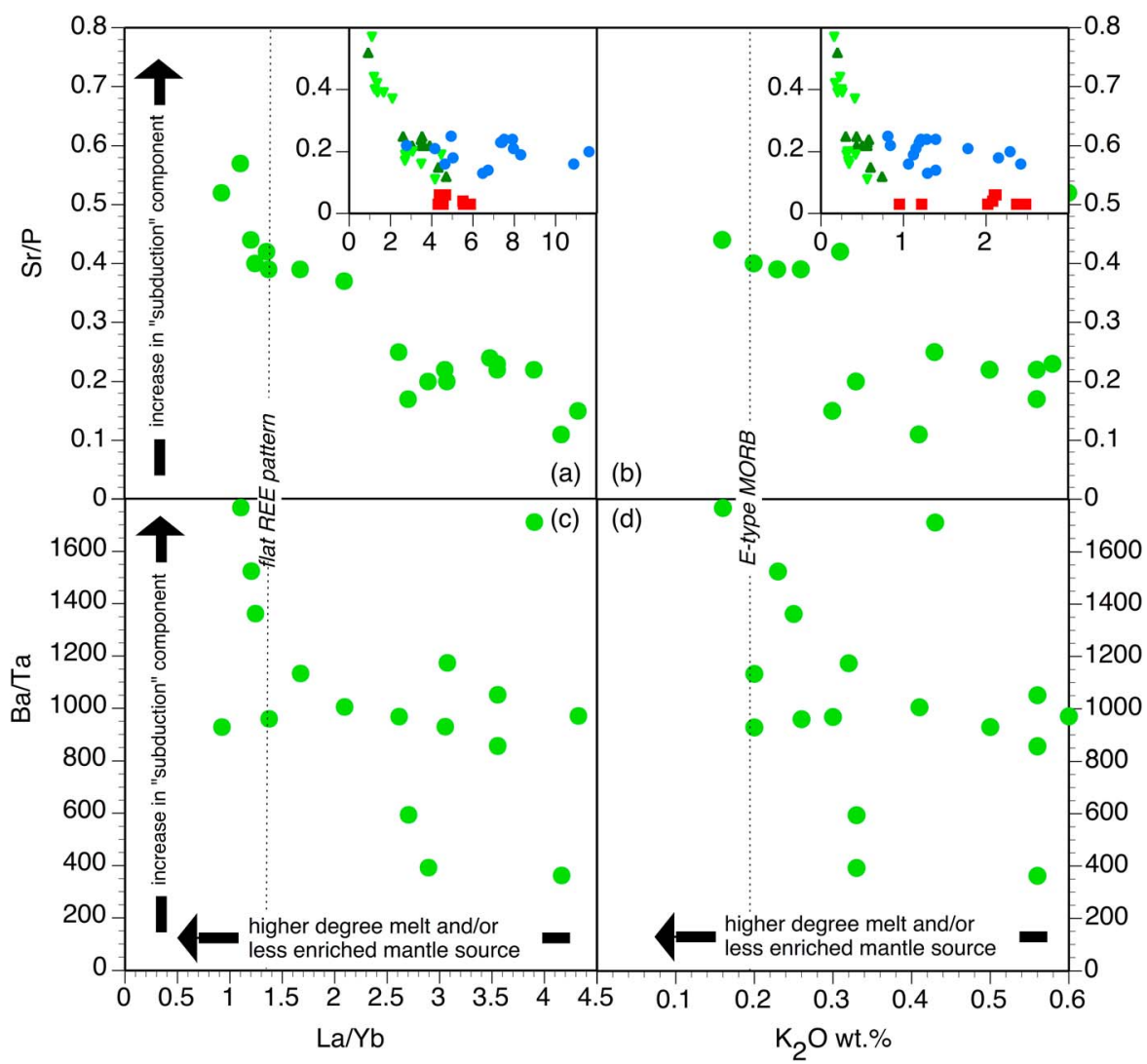

Figure 9. Elemental variations among high-Mg HAOT are inconsistent with variable proportion of mantle source components, in particular a subduction component. Compositions lower in $\mathrm{La} / \mathrm{Yb}$ and in $\mathrm{K}_{2} \mathrm{O}$, which records higher degree of melt or a less enriched mantle, also carry higher $\mathrm{Sr} / \mathrm{P}$ and $\mathrm{Ba} / \mathrm{Ta}$, which indicate a stronger subduction signal. Solid circles are HAOT's with $>8$ wt.\% MgO. Insets show compositional spread of all Harney Basin mafic suites with continuous trends from HAOT samples towards the more evolved andesitic samples; symbols as in Figure 3.

parameterized here by $\mathrm{P} / \mathrm{P}^{*}$ for which we invoke selective apatite addition. In contrast to the HAOT suite, $\mathrm{P} / \mathrm{P}^{*}$ declines with differentiation (decreasing $\mathrm{MgO}$ and $\mathrm{FeO}^{*}$ ) in the calcalkaline suite, speaking to the roles of both apatite and $\mathrm{Fe}$-Ti oxide fractionation.

\subsubsection{Simple Mixing}

[51] Variable degrees of magma mixing between depleted and enriched HAOT composition, or a ferrobasalt, such as HBA11, could account for variations in the HAOT suite (particularly Figures 6 and 10, but also Figures 3b, 4a, 4c, 4g, 4h, 8c, 9a, and $9 \mathrm{~b}$ ). But explaining all observed HAOT variations with a simple mixing process of two single magmas leads to inconsistencies in detail and is not realistic as it would require the two liquids to be repeatedly produced for the lifespan of western Harney Basin volcanism. We think it likely that mixing occurred among basaltic magmas, particularly between newly supplied magmas from the mantle and evolved mafic magmas that stalled and fractionated in the crust. If mixing is to play an important role, the mixing members must first be made.

[52] We exclude simple bulk mixing (contamination) with crustal lithologies or bulk mixing with any Harney Basin silicic magma as sole causes for compositional variation of HAOT, as the differentiation path of HAOT does not follow such trends (Figure 10). A small amount of addition of crustal compositions, especially silicic melt, could account for scatter toward crustal compositions along the HAOT array (Figure 10).

\subsection{Calcalkaline Liquid Line of Descent}

[53] The calcalkaline suite includes no samples that can be construed as primitive; the calcalkaline array intersects the HAOT array at about 7 wt. $\% \mathrm{MgO}$ and $10 \mathrm{wt}$. $\% \mathrm{FeO}^{*}$, indicating that the calcalkaline liquid line of descent has an enriched HAOT parent. We use an evolved HAOT as parent to the calcalkaline (and ferro-trachytic) suite. 

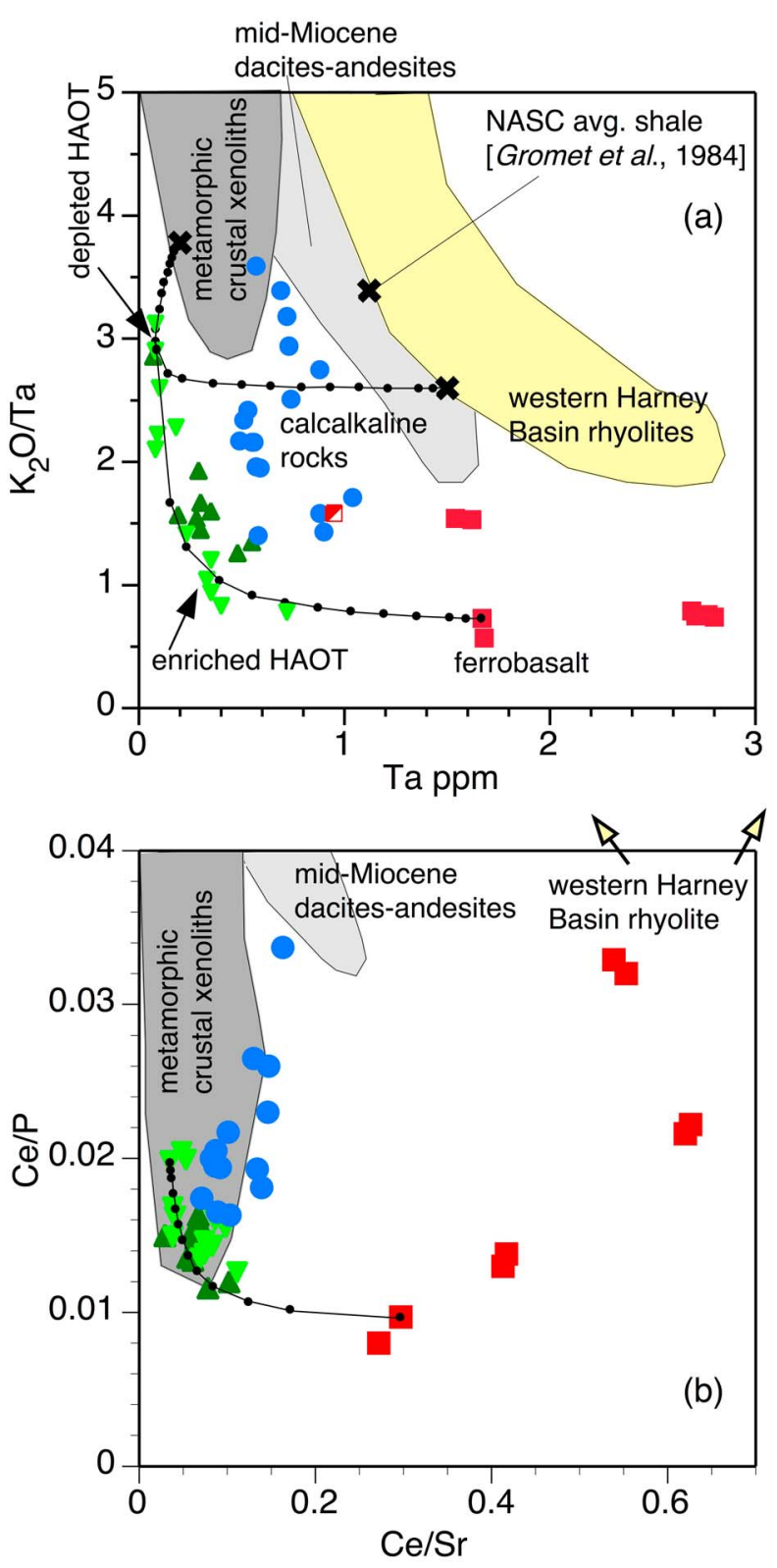

Figure 10. Evaluating bulk mixing scenarios to explain compositional variability of HAOT samples. Shown curves are mixing curves using a depleted HAOT as one mixing member and various other compositions as second mixing member. Ferrobasalt composition (HBA11) yields overall the most consistent results (cf. Figures 2, 3, and 6b); symbols as in Figure 3. Data sources for other Harney Basin lithologies are: metamorphic xenoliths [Streck, 2002]; rhyolites [Maclean, 1994; Streck and Grunder, 1997; Streck and Grunder, 2008]; mid-Miocene dacites-andesites [Maclean, 1994; M. J. Streck and A. L. Grunder, unpublished data, 1994].
[54] As was established by Grove et al. [1982], at Medicine Lake, where HAOT basalts are common, a calcalkaline liquid line of descent is favored over a tholeiitic one by: i) fractionation at high $\mathrm{pH}_{2} \mathrm{O}$ and oxidizing conditions, ii) contamination of the magma through crustal assimilation, or iii) mixing with a crustal (felsic) component. MELTS [Ghiorso and Sack, 1995; Asimow and Ghiorso, 1998] computational experiments bear this out. Fractional crystallization models do not yield sufficiently high $\mathrm{MgO}$ for given $\mathrm{SiO}_{2}$ or $\mathrm{FeO}$ to match calcalkaline basalts; that is, Fe-Ti oxides are not precipitated sufficiently soon for ranges in water content from 0.1 to 0.5 weight percent and at mid to shallow crustal pressures. We cannot invoke high initial $\mathrm{pH}_{2} \mathrm{O}$; melt inclusion and phase equilibria studies indicate at most a few tenths of weight percent water in primitive HAOT compositions [Elkins Tanton et al., 2001; Bartels et al., 1991; Rowe et al., 2009; Till, 2011].

[55] Crustal contamination is further supported by the displacement of the calcalkaline array toward higher $\mathrm{K}_{2} \mathrm{O}$ relative to Ta, that is toward felsic compositions, relative to the tholeiitic array (Figure 10a). Either mid-Miocene dacites and andesites or local rhyolites make a suitable contaminant. Only few are consistent with contamination with metamorphic rocks sampled as mafic xenoliths in the Rattlesnake Tuff. Displacement of the calcalkaline array about one quarter of the distance to the rhyolite field from the HAOT array allows for $25 \%$ contamination of tholeiitic basalt with rhyolite, not accounting for Ta enrichment induced by concomitant crystallization. AFC bulk compositional calculations require some (10-20\%) fractionation of a plagioclase-free, or plagioclase-poor assemblage from a HAOT parent to allow for high (17 plus) weight percent $\mathrm{Al}_{2} \mathrm{O}_{3}$ in calcalkaline basalts and to offset contamination with felsic constituents, which all have $\mathrm{Al}_{2} \mathrm{O}_{3}$ well below 17 wt. $\%$ (13-11 wt.\% is typical).

[56] AFC calculations to model trace element concentration of calcalkaline andesites favor increase in the amount of contamination with Harney Basin rhyolite over increased fractionation from an enriched HAOT parent (e.g., HBA10.1) to obtain an elemental match. Crystal fractionation increases HREE concentration, but the calcalkaline suite has the same or slightly lower HREE concentration compared to enriched HAOT while $\mathrm{La} / \mathrm{Yb}$ increases substantially (Table 1 and Figure 4). The contaminant must have low HREE, preferably lower than the parent magma. Only some Harney Basin rhyolites are suitable contaminants, with HREE concentrations less than in enriched HAOT. In this regard, straight mixing 

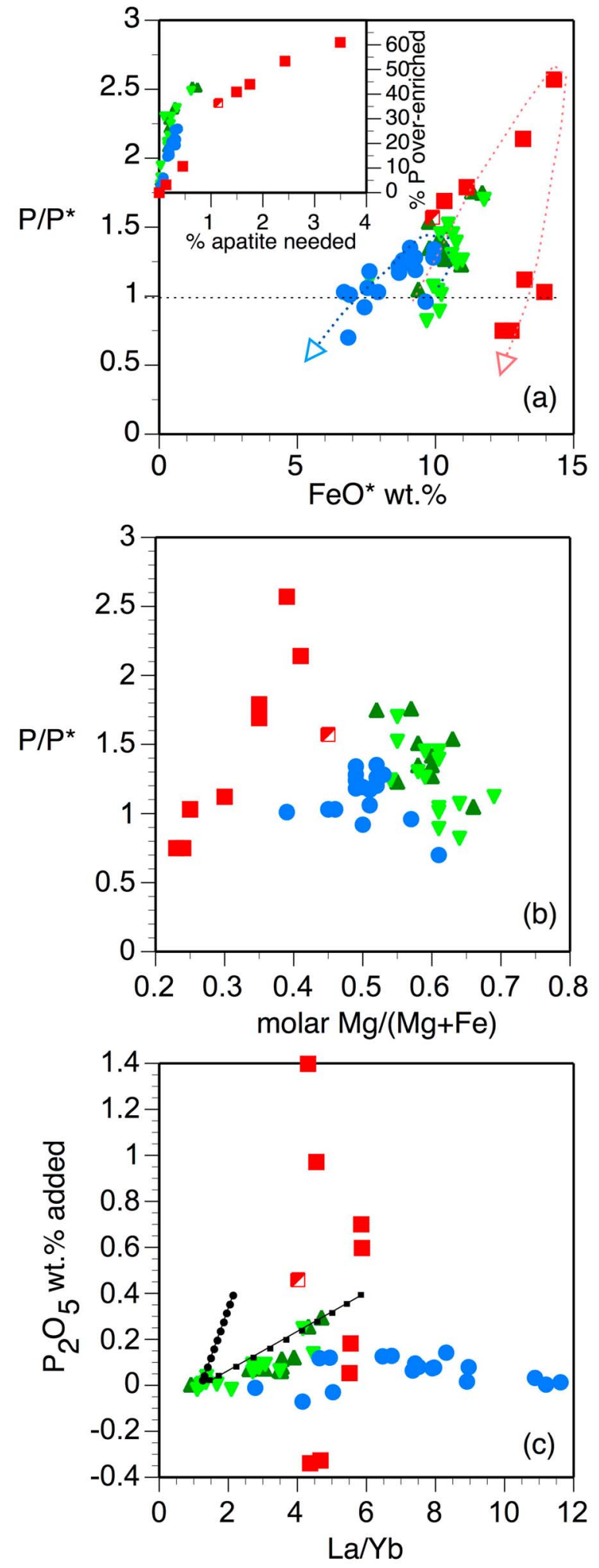

scenarios between rhyolite and HAOT model the andesites almost as well as AFC. Using a straight mixing model suggests about $20-30 \%$ rhyolite, consistent with the systematics illustrated in Figure 10a. A good match is achieved with respect to LILE, LREE and incompatible HFSE for many of the rhyolites.

\subsection{Ferro-trachytic Liquid Line of Descent}

[57] To achieve the high Fe concentrations of the ferro-trachytic suite precludes significant removal of Fe-Ti oxide. Simultaneously, incompatible elements are exceedingly enriched, but maintain concentrations patterns similar to HAOT. Such enrichments can be achieved through repeated fractionation and recharge, keeping recharge rates high and percent fractionation just below the threshold for Fe-Ti oxide. The ferro-trachytic mafic inclusions in the Rattlesnake Tuff have been modeled as recharge dominated compositions (with some contamination by rhyolite). Enrichments in trace element concentrations modeled by $1: 1$ recharge of the magma before fractionation of 50\% (up to ten cycles) produces modest enrichments. Evolved inclusions model well with $50 \%$ fractionation followed by $1: 1$ recharge of the residual magma in up to ten cycles [Streck and Grunder, 1999]. This is similar to the model calculations of Maclean [1994] using a zone refining model [Cox et al., 1979] as an analog for recharge and fractionation. Trace element trajectories from HAOT to Paiute Butte compositions can be accomplished with a fractionating assemblage of ol:pl:cpx:timt of 60:25:10:5 [Maclean,

Figure 11. $\mathrm{P} / \mathrm{P}^{*}$ is the ratio of observed phosphorous (P) concentration to a hypothetical phosphorous concentration $\left(\mathrm{P}^{*}\right)$ obtained through interpolation between mantle normalized values of $\mathrm{Ce}$ and $\mathrm{Nd}$. The ratio indicates whether there is a positive $(>1)$ or negative $(<1) \mathrm{P}$ anomaly in a mantle normalized element diagram (cf. Figure 5) and is used to express over-enrichment of $\mathrm{P}$ in many Harney Basin basaltic samples. Note (a) positive correlation of total $\mathrm{FeO}$ and $\mathrm{P} / \mathrm{P}^{*}$ in and (b) negative correlation with $\mathrm{Mg} \#$ in HAOT and ferro-trachytic suites until apatite starts crystallizing. Dashed lines indicate evolutionary trends observed within ferro-trachytic (red) and calcalkaline (blue) suites. Inset in Figure 11a shows how much apatite uptake would be needed to explain any given over-enrichment and the percentage of how much of the observed $\mathrm{P}_{2} \mathrm{O}_{5}$ concentrations is "overenriched"; (c) ' $\mathrm{P}_{2} \mathrm{O}_{5}$ wt.\% added' is $\mathrm{P}-\mathrm{P}$ * recalculated to wt. $\% \mathrm{P}_{2} \mathrm{O}_{5}$. Superimposed on natural data are model calculations adding two different apatites to depleted HAOT up to $1 \%$ apatite addition (circles = apatite from Pinatubo basalt; squares $=$ apatite from dacitic Cebolla Creek Tuff, see text for discussion). Symbols as in Figure 3. 


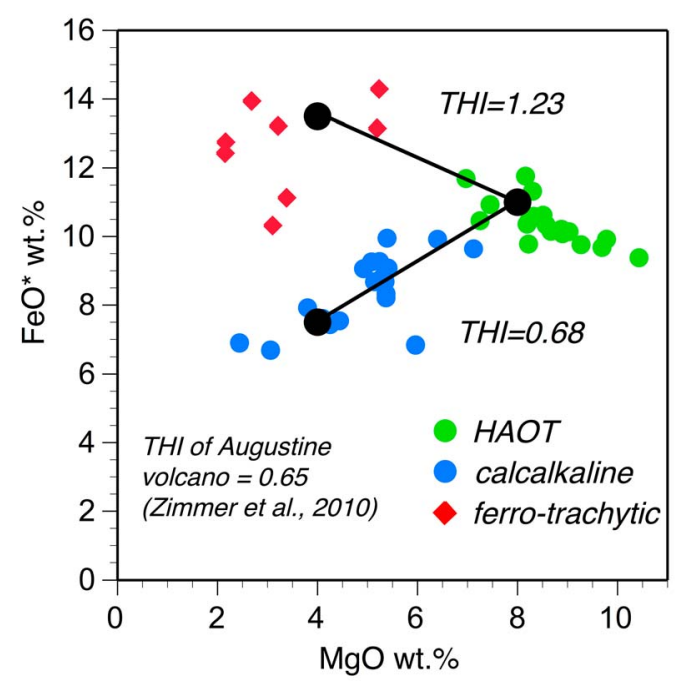

Figure 12. $\mathrm{FeO}^{*}$ versus $\mathrm{MgO}$ wt.\% for the three western Harney Basin compositional suites. THI is Tholeiitic index according to Zimmer et al. [2010]. Values above 1 indicate a tholeitiic trend, values below 1 indicate a calcalkaline trend. The Harney Basin calcalkaline suite is as strongly calcalkaline as is observed within active volcanic arc settings associated with subduction.

1994, Appendix 5] and require at least 9 cycles of recharge.

\subsection{Crustal Effects}

[58] HAOT basalts become of regional significance in the High Lava Plains between 10.5 to $8 \mathrm{Ma}$, with a province-wide peak in activity close to $8 \mathrm{Ma}$. They intermittently persist until the Holocene [Jordan et al., 2004]. Most of this record is represented in the western Harney Basin, where the peak pulse of regional HAOT volcanism heralds the westward passage of rhyolite volcanism. The peak in basaltic volcanism signals the lacing and intraplating of the crust by abundant basalts as mantle-derived tholeiites traverse the crust and warm it. Persistent basaltic magmatism culminated in creating a hot, hybrid protolith, from which felsic melts were extracted, such as the parental rhyolite to the Rattlesnake Tuff rhyolite suite [Streck, 2002; Streck and Grunder, 2008], and that served as contaminants to engender calcalkaline magmas. The calcalkaline suite mainly ranges from 7.6 to $6.7 \mathrm{Ma}$, that is from a few hundred thousand years before to a few hundred thousand years after the main pulse of rhyolite activity as expressed mainly by the Rattlesnake Tuff (Figures 1 and 2). The crustally contaminated calcalkaline suite is an indicator of a crustal column warm and fertile enough to readily hybridize mafic magma with crustal extracts developing a strongly calcalkaline trend (Figure 12). Basaltification of the crust results from intraplating of basalt, the accumulation of the crystal cumulates from erupted basalt and from the extraction of rhyolite to the upper crust. Recharge and fractionation of basalts occurs in mafic chambers some of which are trapped beneath voluminous felsic magma, which, in turn, is thermally sustained by the mafic system, accounting for basaltic andesitic magmatic inclusions in the Rattlesnake Tuff [Streck and Grunder, 1999]. As the crust becomes more mafic, the locus of recharging mafic chambers can rise, enhancing the chances of eruption of such magma which manifested itself in the eruption of Ferich magmas in the waning stages of magmatism in the western Harney Basin. In addition to recharging chambers to make the ferro-trachytic suite, magmatic crustal differentiation is observed in polybaric fractionation of basalts traversing the crust from their mantle sources with little crustal influence but of which some may encounter evolved batches of mafic magmas and mix.

\section{Conclusions}

[59] High alumina olivine tholeiites (HAOT) typify abundant Miocene to Recent basaltic volcanism in the High Lava Plains of Oregon and extend into the adjacent Basin and Range, Owyhee Plateau and Cascade Range. In the central High Lava Plains (western Harney Basin), HAOT magmatism occurred from $\sim 8$ to $2 \mathrm{Ma}$, creating a tholeiitic suite that gave rise to a calcalkaline suite during the time of substantial rhyolite volcanism and a ferro-trachytic suite mainly thereafter. Each suite has its distinct liquid line of descent which was induced by variation in crustal differentiation processes and which seems to have changed in the course of basaltification of the continental crust under the High Lava Plains.

[60] The three suites - the tholeiitic, calc-alkaline and ferro-trachytic - are ultimately derived from depleted HAOT, which was generated from a mantle source that did not change significantly. Most of the chemical variability of the tholeiitic suite, which ranges from depleted (e.g., $\left.\mathrm{La}_{\mathrm{N}} / \mathrm{Yb}_{\mathrm{N}} \leq 1\right)$ to enriched $\left(\mathrm{La}_{\mathrm{N}} / \mathrm{Yb}_{\mathrm{N}} \sim 3\right)$ HAOT, can be ascribed to crystal fractionation in combination with crustal assimilation to account for slight tilt in incompatible trace element pattern and $\mathrm{P}$ overenrichment. Both features can be explained by selective assimilation of apatite although a silicic partial melt could also play a role in shifting REE pattern. Recharge cycles and mixing with highly fractionated ferrobasaltic melts are permissible and would have helped to boost incompatible trace element levels. 
[61] Compositional trends in the calcalkaline and ferro-trachytic suites diverge from enriched HAOT, making for distinctive bifurcated trends in the suites overall. The calcalkaline suite is the only one where $\mathrm{Fe}$ declines with $\mathrm{Mg}$ and that is associated with more strongly tilted incompatible trace element patterns (e.g., $\mathrm{La}_{\mathrm{N}} / \mathrm{Yb}_{\mathrm{N}}$ up to 8 ) and higher $\mathrm{Si}$ (up to andesite). This trend is caused by crustal contamination coupled with crystal fractionation. The ferrotrachytic suite has great incompatible trace element enrichments with normalized elemental patterns paralleling those of enriched HAOT along with increased $\mathrm{Fe}$, small changes in $\mathrm{Si}$, and no changes in isotopic ratios. The ferro-trachytic liquid line of descent originates by recharge and fractionation with some internal mixing between more and less differentiated magmas.

[62] The western Harney Basin volcanic suite exemplifies mutual effects of magma and continental crust, in this case a $\sim 40-\mathrm{km}$-thick crust made of accreted terranes. Crustal assimilation drives a strongly calcalkaline trend from a tholeiitic parent (THI index for our suite is 0.68 compared to 0.65 for Augustine volcano [cf. Zimmer et al., 2010]). Contamination is fueled by persistent basalt flux that promotes crustal melting and basalt interaction with those melts. The calcalkaline suite demonstrates that neither mantlederived calcalkaline basalt nor a subduction setting is a prerequisite to developing a strongly calcalkaline trend. The protracted basalt magmatism also creates a more mafic crust, which, during thermal waning stage, facilitates eruption of highly incompatible trace element enriched ferro-trachytic magmas that differentiated from HAOT by recharge and fractionation.

\section{Acknowledgments}

[63] We extend thanks to the High Lava Plains team for discussions. We thank Charlie Bacon and Rick Conrey for insightful reviews. Bob Duncan and John Huard generously dated one more rock, which Rick Carlson helped to collect. This work was supported by National Science Foundation (EAR-9220500 to A. Grunder and EAR-9725166 to A. Grunder, R. Duncan, and D. Graham) and PSU faculty enhancement grant to M. Streck. Early work of this study was done by the first author when he was supported by the Deutsche Forschungsgemeinschaft, DFG at GEOMAR, Kiel, Germany during a post-doctoral appointment.

\section{References}

Asimow, P. D., and M. S. Ghiorso (1998), Algorithmic modifications extending MELTS to calculate subsolidus phase relations, Am. Mineral., 83, 1127-1131.

Bacon, C. R., P. E. Bruggman, R. L. Christiansen, M. A. Clynne, J. M. Donnelly Nolan, and W. Hildreth (1997),
Primitive magmas at five Cascade volcanic fields: Melts from hot, heterogenous sub-arc mantle, Can. Mineral., 35, 397-423.

Bailey, D. G., and R. M. Conrey (1992), Common parent magma for Miocene to Holocene mafic volcanism in the northwestern United States, Geology, 20, 1131-1134, doi:10.1130/0091-7613(1992)020<1131:CPMFMT>2.3.CO;2.

Bartels, K. S., R. J. Kinzler, and T. L. Grove (1991), High pressure phase relations of primitive high-alumina basalts from Medicine Lake volcano, northern California, Contrib. Mineral. Petrol., 108, 253-270, doi:10.1007/BF00285935.

Belousova, E. A., W. L. Griffin, S. Y. O'Reilly, and N. I. Fisher (2002), Apatites as an indicator mineral for mineral exploration: Trace-element compositions and their relationship to host rock type, J. Geochem. Explor., 76, 45-69, doi:10.1016/S0375-6742(02)00204-2.

Borg, L. E., J. Blichert-Toft, and M. A. Clynne (2002), Ancient and modern subduction zone contributions to the mantle source of lavas from the Lassen region of California inferred from Lu-Hf isotopic systematics, J. Petrol., 43, 705-723, doi:10.1093/petrology/43.4.705.

Brandon, A. D., P. R. Hooper, G. G. Goles, and R. S. J. Lambert (1993), Evaluating crustal contamination in continental basalts: The isotopic composition of the Picture Gorge Basalt of the Columbia River Basalt Group, Contrib. Mineral. Petrol., 114, 452-464, doi:10.1007/BF00321750.

Broderick, C. A. (2008), The origin of sulfur-rich apatites in silicic magmas, MS thesis, 183 pp., Portland State Univ., Portland, Oreg. [Available at http://geomechanics.geology. pdx.edu/geolinq/thesis/thesisList.php.]

Camp, V. E., and M. E. Ross (2004), Mantle dynamics and genesis of mafic magmatism in the intermontane Pacific Northwest, J. Geophys. Res., 109, B08204, doi:10.1029/ 2003JB002838.

Carlson, R. W. (1984), Isotopic constraints on Columbia River flood basalt genesis and the nature of the subcontinental mantle, Geochim. Cosmochim. Acta, 48(11), 2357-2372, doi:10.1016/0016-7037(84)90231-X.

Carlson, R. W., and W. K. Hart (1987), Crustal genesis on the Oregon Plateau, J. Geophys. Res., 92, 6191-6206, doi:10.1029/ JB092iB07p06191.

Catchings, R. D., and W. D. Mooney (1988), Crustal structure of east central Oregon: Relationships between Newberry volcano and regional crustal structure, J. Geophys. Res., 93(B9), 10,081-10,094, doi:10.1029/JB093iB09p10081.

Chu, M.-F., K.-L. Wang, W. L. Griffin, S.-L. Chung, S. Y. O'Reilly, N. J. Pearson, and Y. Iizuka (2009), Apatite composition: Tracing petrogenetic processes in transhimalayan granitoids, J. Petrol., 50, 1829-1855, doi:10.1093/petrology/ egp054.

Conrey, R. M., D. R. Sherrod, P. R. Hooper, and D. A. Swanson (1997), Diverse primitive magmas in the Cascade Arc, northern Oregon and southern Washington, Can. Mineral., 35, 367-396.

Conrey, R. M., E. M. Taylor, J. M. Donnelly Nolan, and D. R. Sherrod (2002), North-central Oregon Cascades: Exploring petrologic and tectonic intimacy in a propagating intra-arc rift, Oreg. Dep. Geol. Miner. Ind. Spec. Pap., 36, 47-90.

Cox, K. G., J. D. Bell, and R. J. Pankhurst (1979), The Interpretation of the Igneous Rocks, George Allen and Unwin, London.

Draper, D. S. (1991), Late Cenozoic bimodal magmatism in the northern Basin and Range Province of southeastern Oregon, J. Volcanol. Geotherm. Res., 47, 299-328, doi:10.1016/ 0377-0273(91)90006-L. 
Eagar, K. C., M. J. Fouch, D. E. James, and R. W. Carlson (2011), Crustal structure beneath the High Lava Plains of eastern Oregon and surrounding regions from receiver function analysis, J. Geophys. Res., 116, B02313, doi:10.1029/ 2010JB007795.

Edwards, B. R., and J. K. Russell (1998), Timescales of magmatic processes: New insights from dynamic models for magmatic assimilation, Geology, 26, 1103-1106, doi:10.1130/ 0091-7613(1998)026<1103:TSOMPN $>2.3 . C O ; 2$

Eiler, J., E. M. Stolper, and M. C. McCanta (2011), Intra- and intercrystalline oxygen isotope variations in minerals from basalts and peridotites, J. Petrol., 52(7-8), 1393-1413, doi:10.1093/petrology/egr006.

Elkins Tanton, L. T., T. L. Grove, and J. Donnelly Nolan (2001), Hot shallow melting under the Cascades volcanic arc, Geology, 29(7), 631-634, doi:10.1130/0091-7613(2001) $029<0631:$ HSMMUT>2.0.CO;2.

Ford, M. T. (2011), Rhyolitic mgmatism of the High Lava Plains and adjacent northwestern Basin and Range, Oregon: Implications for evolution of the continental crust, $\mathrm{PhD}$ thesis, 314 pp., Oreg. State Univ., Corvallis.

Ghiorso, M. S., and R. O. Sack (1995), Chemical mass transfer in magmatic processes. IV. A revised and internally consistent thermodynamic model for the interpolation and extrapolation of liquid-solid equilibria in magmatic systems at elevated temperatures and pressures, Contrib. Mineral. Petrol., 119, 197-212, doi:10.1007/BF00307281.

Graham, D. W., M. R. Reid, B. T. Jordan, A. L. Grunder, W. P. Leeman, and J. E. Lupton (2009), Mantle source provinces beneath northwestern USA delimited by helium isotopes in young basalts, J. Volcanol. Geotherm. Res., 188(1-3), 128-140, doi:10.1016/j.jvolgeores.2008.12.004.

Greene, R. C., G. W. Walker, and R. E. Corcoran (1972), Geologic map of the Burns quadrangle, Oregon, U.S. Geol. Surv. Map, I-680.

Gromet, L. P., R. F. Dymek, L. A. Haskin, and R. L. Korotev (1984), The "North American shale composite": It's compilation, major and trace element characteristics, Geochim. Cosmochim. Acta, 48, 2469-2482, doi:10.1016/0016-7037(84)90298-9.

Grove, T. L., D. C. Gerlach, and T. W. Sando (1982), Origin of calcalkaline series lavas at Medicine Lake volcano by fractionation, assimilation and mixing, Contrib. Mineral. Petrol., 80(2), 160-182, doi:10.1007/BF00374893.

Harrison, T. M., and E. B. Watson (1984), The behavior of apatite during crustal anatexis: Equilibrium and kinetic considerations, Geochim. Cosmochim. Acta, 48, 1467-1477, doi:10.1016/0016-7037(84)90403-4.

Hart, S. R., and T. Dunn (1993), Experimental cpx/melt partitioning of 24 trace elements, Contrib. Mineral. Petrol., 113, 1-8, doi:10.1007/BF00320827.

Hart, W. K. (1985), Chemical and isotopic evidence for mixing between depleted and enriched mantle, northwestern U.S.A, Geochim. Cosmochim. Acta, 49, 131-144, doi:10.1016/ 0016-7037(85)90197-8.

Hart, W. K., J. L. Aronson, and S. A. Mertzman (1984), Areal distribution and age of low-K, high-alumina olivine tholeitte magmatism in the northwestern Great Basin, Geol. Soc. Am. Bull., 95, 186-195, doi:10.1130/0016-7606(1984)95<186: ADAAOL $>2.0 . \mathrm{CO} ; 2$.

Hart, W. K., R. W. Carlson, and S. B. Shirey (1997), Radiogenic Os in primitive basalts from the northwestern U.S.A.: Implications for petrogenesis, Earth Planet. Sci. Lett., 150, 103-116, doi:10.1016/S0012-821X(97)00075-7.

Hauri, E. H., T. P. Wagner, and T. L. Grove (1994), Experimental and natural partitioning of $\mathrm{Th}, \mathrm{U}, \mathrm{Pb}$, and other trace elements between garnet, clinopyroxene and basaltic melts, Chem. Geol., 117, 149-166, doi:10.1016/0009-2541(94) 90126-0.

Hirose, K., and I. Kushiro (1993), Partial melting of dry peridotites at high pressures: Determination of compositions of melt segregated from peridotite using aggregates of diamond, Earth Planet. Sci. Lett., 114, 477-489, doi:10.1016/0012821X(93)90077-M.

Hooper, P. R., W. K. Steele, R. M. Conrey, G. A. Smith, J. L. Anderson, D. G. Bailey, M. H. Beeson, T. L. Tolan, and K. M. Urbanczyk (1993), The Prineville basalt, north-central Oregon, Oreg. Geol., 55, 3-12.

Iademarco, M. J. (2009), Volcanism and faulting along the northern margin of Oregon's High Lava Plains: Hampton Butte to Dry Mountain, MS thesis, 58 pp., Oreg. State Univ., Corvallis.

Irvine, T. N., and W. R. A. Baragar (1971), A guide to the chemical classification of the common volcanic rocks, Can. J. Earth Sci., 8, 523-548, doi:10.1139/e71-055.

Johnson, D. M., P. R. Hooper, and R. M. Conrey (1999), XRF analysis of rocks and minerals for major and trace elements on a single low dilution Li-tetraborate fused bead, $A d v . X$-Ray Anal., 41, 843-867.

Johnson, J. A., C. J. Hawkesworth, P. R. Hooper, and G. B. Binger (1998), Major- and trace-element analyses of Steens Basalt, southeastern Oregon, U.S. Geol. Surv. Open File Rep., 98-482, 25 pp.

Jordan, B. J., A. L. Grunder, and B. K. Nelson (2002), Basaltic volcanism of the Oregon High Lava Plains, Geol. Soc. Am. Abstr. Programs, 34(5), 37.

Jordan, B. J., A. L. Grunder, R. Duncan, and A. Deino (2004), Geochronology of age-progressive volcanism of the Oregon High Lava Plains: Implications for the plume interpretation of Yellowstone, J. Geophys. Res., 109, B10202, doi:10.1029/ 2003JB002776.

Jordan, B. T. (2001), Tectonism and mafic volcanism of the High Lava Plains, eastern Oregon, $\mathrm{PhD}$ thesis, Oreg. State Univ., Corvallis.

Kelemen, P. B. (1990), Reaction between ultramafic rock and fractionating basaltic magma. I. Phase relations, the origin of calc-alkaline magma series, and the formation of discordant dunite, J. Petrol., 31, 51-98.

Knaack, C., S. B. Cornelius, and P. R. Hooper (1994), Trace element analyses of rocks and minerals by ICP-MS, Open File Rep., Wash. State Univ., Pullman. [Available at http:// www.sees.wsu.edu/Geolab/note/icpms.html.]

Langmuir, C. H., E. M. Klein, and T. Plank (1992), Petrological systematics of mid-ocean ridge basalts: Constraints on melt generation beneath ocean ridges, in Mantle Flow and Melt Generation at Mid-Ocean Ridges, Geophys. Monogr. Ser., vol. 71, edited by J. P. Morgan, D. K. Blackman, and J. M. Sinton, pp. 183-280, AGU, Washington, D. C., doi:10.1029/GM071p0183.

Le Bas, M. J., R. W. Le Maitre, A. Streckeisen, and B. Zanettin (1986), A chemical classification of volcanic rocks based on the total alkali-silica diagram, J. Petrol., 27, 745-750.

Leeman, W. P. (1982), Rhyolites of the Snake River PlainYellowstone Plateau province, Idaho and Wyoming, A summary of petrogenetic models, in Cenozoic Geology of Idaho, edited by W. Bonnichsen and R. M. Brekenridge, Bur. Mines Geol. Bull., 26, 203-212.

Leeman, W. P., C. J. Vitaliano, and M. Prinz (1976), Evolved lavas from the Snake River Plain: Craters of the Moon National Monument, Idaho, Contrib. Mineral. Petrol., 56, 35-60, doi:10.1007/BF00375420. 
Leeman, W. P., J. F. Lewis, R. C. Evarts, R. M. Conrey, and M. J. Streck (2005), Petrologic constraints on the thermal structure of the southern Washington Cascades, J. Volcanol. Geotherm. Res., 140, 67-105.

Maclean, J. W. (1994), Geology and geochemistry of Juniper Ridge, Horsehead Mountain and Burns Butte: Implications for the petrogenesis of silicic magma on the High Lava Plains, southeastern Oregon, MS thesis, 141 pp., Oreg. State Univ., Corvallis.

MacLeod, N. S., G. W. Walker, and E. H. McKee (1976), Geothermal significance of eastward increase in age of upper Cenozoic rhyolitic domes in southeastern Oregon, paper presented at Second United Nations Symposium on the Development and Use of Geothermal Resources, San Francisco.

McDonough, W. F., and S.-S. Sun (1995), The composition of the Earth, Chem. Geol., 120, 223-253, doi:10.1016/00092541(94)00140-4.

Niem, A. (1974), Wright's Point, Harney County, Oregon: An example of inverted topography, Ore Bin, 36(3), 33-49.

O'Hara, M. J., and R. E. Mathews (1981), Geochemical evolution in an advancing, periodically replenished, periodically tapped, continuously fractionated magma chamber, J. Geol. Soc., 138, 237-277, doi:10.1144/gsjgs.138.3.0237.

Robinson, P. T. (1969), High-titania alkali-olivine basalts of north-central Oregon, U.S.A, Contrib. Mineral. Petrol., 22, 349-360, doi:10.1007/BF00400129.

Rowe, M., A. J. R. Kent, and R. L. Nielsen (2009), Subduction influence on oxygen fugacity and trace elements and volatiles across the Cascades arc, J. Petrol., 50(1), 61-91, doi:10.1093/petrology/egn072.

Scarberry, K. C., A. J. Meigs, and A. L. Grunder (2010), Inception and style of faulting at the edge of a propagating continental rift system: Insight from the structural development of the Abert Rim Fault, Southern Oregon, Tectonophysics, 488(1-4), 71-86, doi:10.1016/j.tecto.2009.09.025.

Schmidt, M. E., A. L. Grunder, and M. Rowe (2008), Segmentation of the Cascades Arc as indicated by $\mathrm{Sr}$ and $\mathrm{Nd}$ isotopic variation among primitive basalts, Earth Planet. Sci. Lett., 266, 166-181, doi:10.1016/j.epsl.2007.11.013.

Spera, F. J., and W. A. Bohrson (2004), Open-system magma chamber evolution: An energy-constrained geochemical model incorporating the effects of concurrent eruption, recharge, variable assimilation and fractional crystallization (EC-E'RA $\chi$ FC), J. Petrol., 45, 2459-2480, doi:10.1093/ petrology/egh072.

Streck, M. J. (1994), Volcanology and petrology of the Rattlesnake Ash-Flow Tuff, eastern Oregon, PhD thesis, 185 pp., Oreg. State Univ., Corvallis.

Streck, M. J. (2002), Partial melting to produce high-silica rhyolites of a young bimodal suite: Compositional constraints among rhyolites, basalts, and metamorphic xenoliths from the Harney Basin, Oregon, Int. J. Earth Sci., 91, 583-593, doi:10.1007/s00531-001-0246-7.

Streck, M. J., and A. L. Grunder (1995), Crystallization and welding variations in a widespread ignimbrite sheet; The Rattlesnake Tuff, eastern Oregon, USA, Bull. Volcanol., 57, 151-169.

Streck, M. J., and A. L. Grunder (1997), Compositional gradients and gaps in high-silica rhyolites of the Rattlesnake Tuff, Oregon, J. Petrol., 38, 133-163, doi:10.1093/petroj/ 38.1 .133
Streck, M. J., and A. L. Grunder (1999), Enrichment of basalt and mixing of dacite in the rootzone of a large rhyolite chamber: Inclusions and pumices from the Rattlesnake Tuff, Oregon, Contrib. Mineral. Petrol., 136, 193-212, doi:10.1007/ s004100050532.

Streck, M. J., and A. L. Grunder (2008), Phenocryst-poor rhyolites of bimodal, tholeiitic provinces: The Rattlesnake Tuff and implications for mush extraction models, Bull. Volcanol., 70, 385-401, doi:10.1007/s00445-007-0144-3.

Sun, S.-S., and W. F. McDonough (1989), Chemical and isotopic systematics of oceanic basalts: Implications for mantle composition and processes, in Magmatism in the Ocean Basin, edited by A. D. Saunders and M. J. Norry, Geol. Soc. Spec. Publ., 42, 313-345.

Till, C. B. (2011), Melt generation in the Earth's mantle at subduction zones, $\mathrm{PhD}$ thesis, Mass. Inst. Technol., Cambridge, Mass.

Toplis, M. J., G. Libourel, and M. R. Carroll (1994), The role of phosphorous in crystallization processes of basalt: An experimental study, Geochim. Cosmochim. Acta, 58, 797-810, doi:10.1016/0016-7037(94)90506-1.

Trench, D., A. J. Meigs, and A. L. Grunder (2012), Termination of the northwestern Basin and Range Province into a clockwise rotating region of trantension and volcanism, southeast Oregon, J. Struct. Geol., 39, 52-65, doi:10.1016/ j.jsg.2012.03.007.

Van Hoose, A. (2011), Apatite crystal populations of the 1991 Mount Pinatubo eruption, Philippines: Implications for the generation of high sulfur apatite in silicic melts, MS thesis, Portland State Univ., Portland, Oreg. [Available at http://geomechanics.geology.pdx.edu/geolinq/thesis/thesisList. php.]

Walker G. W. (1979), Revisions to the Cenozoic stratigraphy of Harney basin, southeastern Oregon., U.S. Geol. Surv. Bull., 1475, 1-35.

Walker G. W., N. V. Peterson, and R. C. Greene (1967), Reconnaissance geologic map of the east half of the Crescent quadrangle, Lake, Deschutes, and Crook counties, Oregon, U.S. Geol. Surv. Map, I-493.

Watson, E. B., and C. J. Capobianco (1981), Phosphorus and rare earth elements in felsic magmas: An assessment of the role of apatite, Geochim. Cosmochim. Acta, 45(12), 2349-2358, doi:10.1016/0016-7037(81)90088-0.

Wiebe, R. A., D. Smith, M. Sturm, E. M. King, and M. S. Seckler (1997), Enclaves in the Cadillac Mountain granite (coastal Maine): Samples of hybrid magma from the base of the chamber, J. Petrol., 38, 393-423, doi:10.1093/petroj/ 38.3.393.

Zimmer, M. M., T. Plank, E. H. Hauri, G. M. Yogodzinski, P. Stelling, J. Larsen, B. Singer, B. Jicha, C. Mandeville, and C. J. Nye (2010), The role of water in generating the calc-alkaline trend: New volatile data for aleutian magmas and a new tholeiitic index, J. Petrol., 51, 2411-2444, doi:10.1093/petrology/egq062.

Zou, H., and M. R. Reid (2001), Quantitative modeling of trace elements fractionation during incongruent dynamic melting, Geochim. Cosmochim. Acta, 65, 153-162, doi:10.1016 S0016-7037(00)00505-6. 